\title{
Identification and Characterization of Oleaginous Yeast Isolated from Kefir and Its Ability to Accumulate Intracellular Fats in Deproteinated Potato Wastewater with Different Carbon Sources
}

\author{
Iwona Gientka, Marek Kieliszek, Karolina Jermacz, and Stanisław Błażejak \\ Department of Biotechnology, Microbiology and Food Evaluation, Faculty of Food Science, \\ Warsaw University of Life Sciences-SGGW, Nowoursynowska Str. 159c, 02-776 Warsaw, Poland \\ Correspondence should be addressed to Iwona Gientka; iwona_gientka@sggw.pl
}

Received 27 April 2017; Revised 6 July 2017; Accepted 18 July 2017; Published 17 September 2017

Academic Editor: Isabelle Chevalot

Copyright (c) 2017 Iwona Gientka et al. This is an open access article distributed under the Creative Commons Attribution License, which permits unrestricted use, distribution, and reproduction in any medium, provided the original work is properly cited.

\begin{abstract}
The search for efficient oleaginous microorganisms, which can be an alternative to fossil fuels and biofuels obtained from oilseed crops, has been going on for many years. The suitability of microorganisms in this regard is determined by their ability to biosynthesize lipids with preferred fatty acid profile along with the concurrent utilization of energy-rich industrial waste. In this study, we isolated, characterized, and identified kefir yeast strains using molecular biology techniques. The yeast isolates identified were Candida inconspicua, Debaryomyces hansenii, Kluyveromyces marxianus, Kazachstania unispora, and Zygotorulaspora florentina. We showed that deproteinated potato wastewater, a starch processing industry waste, supplemented with various carbon sources, including lactose and glycerol, is a suitable medium for the growth of yeast, which allows an accumulation of over $20 \%$ of lipid substances in its cells. Fatty acid composition primarily depended on the yeast strain and the carbon source used, and, based on our results, most of the strains met the criteria required for the production of biodiesel. In particular, this concerns a significant share of saturated fatty acids, such as C16:0 and C18:0, and unsaturated fatty acids, such as C18:1 and C18:2. The highest efficiency in lipid biosynthesis exceeded $6.3 \mathrm{~g} \mathrm{~L}^{-1}$. Kazachstania unispora was able to accumulate the high amount of palmitoleic acid.
\end{abstract}

\section{Introduction}

Oleaginous yeasts are capable of accumulating over $20 \%$ of their cell mass as intracellular lipids and the production of microbiological lipids is defined as SCO (single cell oil) [1]. Oleaginous yeasts primarily belong to the genera Rhodotorula, Rhodosporidium, Cryptococcus, Yarrowia, Trichosporon, and Lipomyces [2-6]. The further exploration of the biological resources of the earth and food environment in this respect is still justified by the need to find new sources of biodiesel or nutritionally valuable fatty acids. Compared to other oleaginous microorganisms, such as filamentous fungi and algae, yeasts have a higher growth rate resulting in higher cell density [7]. Lipids produced by yeasts have similar fatty acid profiles compared to those of vegetable oils and are therefore considered as an alternative strategy for the production of second-generation fuels, including biodiesel $[2,8,9]$.
The high yeast oils concentration and productivity can only be attained if a high yeast cell density is achieved at high productivity during the growth phase. High yeast cell density can only be achieved in well-selected bioreactors. As Koutinas et al. [10] concluded that the high costs represent also the capital and electricity consumption associated with the operation of classical field erected fermenters that are necessary in order to produce the microbial biomass and oil under fed-batch conditions. The engineering sciences have to solve these problems and deliver new solutions. However, also the high cost of culture media makes microbial oils less economically viable [11]. In recent years, it has become evident that biodiesel production should depend on agroindustrial wastes and renewable resources that do not compete with food and feed production. Several lowcost materials have been extensively studied as competitive alternatives for $\mathrm{SCO}$ production to make the production of 
yeast oil become economically viable. It is noteworthy that selection of oleaginous yeast should be directed toward the search for strains that can grow on cheap and available media, for example, the waste generated by the agrifood industry.

In developed countries, the problem of waste utilization, which is one of the most important priorities, needs to be addressed. Starch processing plants are arduous manufacturers of sewage. The production of potato starch involves formation of three types of organic wastes: potato juice, wastewater, and pulp. Potato wastewater is 10 -fold diluted potato juice created during starch milk refining. To reduce the burden on potato wastewater, the starch processing plants perform the process of deproteinization by applying thermalacid coagulation to remove proteins, which is then used in the production of animal feed [12]. Deproteinization step does not free potato wastewater from excess organic compounds [13], which still significantly burdens the wastewater.

Deproteinated potato wastewater (DPW) can act as a growth medium for yeast [14]. It contains raw protein, which includes soluble proteins and peptides, amino acids, minerals, and nitrogenous compounds [15]. The total organic carbon content in DPW is about $14-15 \mathrm{~g} \mathrm{~L}^{-1}[13,16]$, and the concentration of reducing sugars, primarily represented by glucose, rhamnose, and galactose, fluctuates in the range of about $0.5-1 \%$. To achieve a high yield in biomass, DPW must be supplemented with other available carbon sources, which contributes to both biomass yield and the content of intracellular components. In addition to saccharides, glycerol can be utilized as a carbon source in the yeast culture medium. The production of biodiesel involves the formation of crude glycerol, which has been studied for many years [8, 17]. At present, there is an urgent need to tackle the problem of utilization of glycerol because of its increasing annual production rate. As postulated by Almeida et al. [18], it has become a "waste-stream" instead of a valuable "coproduct."

An inconvenient waste of the food industry is whey, which is generated in large quantities by the dairy industry. The possibility of biotechnological management of whey is largely dependent on the abilities of its microorganisms in assimilating or fermenting milk sugar-lactose. Kefir may be the natural environment for the yeast that have the ability to assimilate lactose. Therefore, it can be a source of lactosepositive yeast strains.

Kefir is a fermented milk product manufactured from milk subjected to lactic acid-alcohol fermentation in the presence of kefir grains. Kefir grains have a characteristic microflora that includes lactic acid-fermenting bacteria, acetic acid bacteria, and yeasts [23]. Kefir grains are clusters of symbiotic microorganisms held together by a polysaccharide matrix called kefiran [21], which may constitute up to $25 \%$ dry matter of kefir grains. Kefiran, formed by Lactobacillus kefiranofaciens, is a branched chain polysaccharide that is well soluble in hot water [28-31]. Kefir grains, also called kefir mushrooms, resemble cauliflower florets in their shape and reach up to a size of about $1-3 \mathrm{~cm}$ in diameter; they are not soluble in water and in most of the solvents. The sensory characteristics show that kefir is white or slightly yellow in color and have elastic consistency with compact structure $[19,20,32]$. According to the recommendations of Food and Agriculture Organization (FAO) and World Health
Organization (WHO), $1 \mathrm{~g}$ of kefir should contain a minimum of $10^{4}$ colony forming units (cfu) of yeasts (FAO/WHO Food Standards: CODEX STAN 243-2003). Yeast microflora constituting $10-17 \%$ of kefir grains is predominantly composed of nonfermenting lactose yeasts $(60-100 \%$ of total yeasts number) [23]. This makes them dependent on lactic acid bacteria, which use lactose as the carbon source. The $\mathrm{pH}$ decreases with the progress of lactic acid fermentation (lactic acid is produced), which favors the development of yeast. Yeast, in turn, stimulates the growth of lactic acid bacteria by the production of B-group vitamins and hydrolyze milk proteins by secreting proteolytic enzymes [20, 33]. Despite numerous reports concerning the nature of symbiotic systems in kefir grains, little is known about the formation of those yeasts and their biotechnological potential including their ability to accumulate intracellular fat.

The aim of this investigation was to isolate yeast strains from kefir and to study their biochemical behavior emphasizing their ability to accumulate lipids. The newly isolated strains were identified according to their internal transcribed spacer (ITS) sequence similarities. The studies regarding lipid accumulation abilities and fatty acid composition were performed. The concept of the utilization of potato wastewater as a source of assimilable nitrogen and other essential elements for oleaginous kefir yeast breeding was examined.

\section{Material and Methods}

2.1. Isolation Procedure. Natural kefirs were purchased from Polish manufacturers. All products were examined within their shelf life period. Kefir sample $(10 \mathrm{~g})$ was aseptically withdrawn and suspended in $90 \mathrm{~mL}$ of physiological saline. One $\mathrm{mL}$ culture from this dilution was loaded on Sabouraud dextrose agar with chloramphenicol and incubated at $28^{\circ} \mathrm{C}$ for $72 \mathrm{~h}$. After incubation, the culture was evaluated for bacterial growth, and yeast colonies from the agar plate were transferred using streaking technique on Sabouraud dextrose agar and incubated at $28^{\circ} \mathrm{C}$ again for $72 \mathrm{~h}$. It was then inoculated by streaking on YPD medium (composed of glucose $20 \mathrm{~g} \mathrm{~L}^{-1}$, peptone $20 \mathrm{~g} \mathrm{~L}^{-1}$, yeast extract $10 \mathrm{~g} \mathrm{~L}^{-1}$, and agar $\left.20 \mathrm{~g} \mathrm{~L}^{-1}, \mathrm{pH} 5.5\right)$. The so-obtained strains were stored on YPD agar medium with $\mathrm{pH} 5.6$ at $6^{\circ} \mathrm{C}$, restreaking again on fresh medium every 3-4 weeks.

\subsection{Identification Procedure}

2.2.1. Identification by Phenotypic Characteristic of Isolates. The yeast strains were identified using Api 20 AUX tests [BioMerieux, France] according to the manufacturer's instructions. Prior to testing, the isolates were subcultured on to Sabouraud dextrose agar and were incubated at $28^{\circ} \mathrm{C}$ in an aerobic atmosphere for $24-48 \mathrm{~h}$.

2.2.2. Identification by DNA Restrictions Analysis Method: Molecular Identification DNA Isolation. After $24 \mathrm{~h}$ culture in YPD medium, yeast biomass $\left(2 \mathrm{~cm}^{3}\right)$ was centrifuged at $716 \times \mathrm{g}$ and $4^{\circ} \mathrm{C}$ for $10 \mathrm{~min}$. Then, it was rinsed twice with sterile deionized water and suspended in $300 \mu \mathrm{L}$ lysis buffer (1 mM EDTA; 10 mM Tris-HCl, pH 8.0; 100 mM NaCl; $2 \%$ Triton $\mathrm{X}-100 ; 1 \% \mathrm{SDS})$ and then gently vortexed. The 
precipitate was incubated at a temperature of $37^{\circ} \mathrm{C}$ for $1 \mathrm{~h}$. Then, $200 \mu \mathrm{L}$ of TE buffer $(10 \mathrm{mM}$ Tris- $\mathrm{HCl}, \mathrm{pH} 8.0 ; 1 \mathrm{mM}$ EDTA) was added. Then, $200 \mu \mathrm{L}$ of mixture containing phenol: chloroform : isoamyl alcohol at a ratio of $25: 24: 1$ ( $\mathrm{pH}$ 8.0) was added and vortexed for $60 \mathrm{~s}$. The samples were centrifuged at $4472 \times \mathrm{g}$ at $4^{\circ} \mathrm{C}$ for $10 \mathrm{~min}$, and the upper phase was transferred to new sterile Eppendorf tubes. To this, $1 \mathrm{~mL}$ of $96 \%$ ethanol was added to obtain a precipitate. This precipitate was centrifuged at $8765 \times \mathrm{g}$ for $10 \mathrm{~min}$ at $4^{\circ} \mathrm{C}$ and was washed with ice-cold $70 \%$ ethanol, dried, and suspended in $50 \mu \mathrm{L}$ sterile distilled water [34].

2.2.3. DNA Amplification. DNA was amplified according to a previously described procedure [35]. The following primers were used in this experiment: ITS1 ( $5^{\prime}$ CGG GAT CCG TAG GTG AAC CTG CGG $3^{\prime}$ ) and ITS4 (5' CGG GAT CCT CCG CTT ATT GAT ATG C $3^{\prime}$ ) each at a concentration of $20 \mathrm{pmol}, 1.5 \mathrm{mM} \mathrm{L}^{-1}$ of $\mathrm{MgCl}_{2}, 0.25 \mathrm{mmol} \mathrm{L}^{-1}$ of $\mathrm{dNTP}$, and $0.5 \mathrm{U}$ of Taq polymerase (Fermentas, Lithuania) were added to template DNA with a concentration of $300 \mathrm{ng}_{\mu \mathrm{L}^{-1}}(5 \mu \mathrm{L})$. Amplification reaction was performed in a Mastercycler gradient thermocycler (Eppendorf company) using a program with the following parameters: temperature $94^{\circ} \mathrm{C}-5 \mathrm{~min}$ and then 34 cycles, $94^{\circ} \mathrm{C}-45 \mathrm{~s} ; 60^{\circ} \mathrm{C}-1 \mathrm{~min} ; 72^{\circ} \mathrm{C}-2 \mathrm{~min}$; and $72^{\circ} \mathrm{C}-5 \mathrm{~min}$. PCR reaction products were separated in $2 \%(\mathrm{w} / \mathrm{v})$ agarose gel (Sigma) in $0.5 \mathrm{x}$ TAE buffer $(60 \mathrm{~min}$, $9.5 \mathrm{~V} / \mathrm{cm}$ gel). Molecular weight markers of 1500-100 base pairs (bp) DNA (Thermo Scientific) were used to determine the molecular weight of the unknown bands obtained.

2.2.4. DNA Digestion Using Restriction Enzymes. Two restriction enzymes, namely, HaeIII (Fermentas, Lithuania) and $R s a$ I (Thermo Scientific), were used to digest the amplified DNA fragments as per the manufacturer's protocol. The digestion products were separated using electrophoresis on a $2 \%$ agarose gel (Sigma) in $0.5 x$ TAE buffer and analyzed under UV light.

2.2.5. Phylogenetic Analysis. Amplicons were sequenced using Genomed, Warsaw, Poland. DNA sequences were analyzed with basic local alignment search tool (BLAST). Phylogenetic analysis was performed using MEGA 7 by applying neighbor-joining algorithm [36].

\subsection{Media and Growth Conditions}

2.3.1. Culture Media. The yeast strains were cultured using the following control media: (a) YPGlc containing $20 \mathrm{~g} \mathrm{~L}^{-1}$ peptone, $10 \mathrm{gL}^{-1}$ yeast extract, and $50 \mathrm{gL}^{-1}$ glucose; (b) YPLac containing $20 \mathrm{~g} \mathrm{~L}^{-1}$ peptone, $10 \mathrm{~g} \mathrm{~L}^{-1}$ yeast extract, and $50 \mathrm{~g} \mathrm{~L}^{-1}$ lactose; and (c) YPGly containing $20 \mathrm{~g} \mathrm{~L}^{-1}$ peptone, $10 \mathrm{~g} \mathrm{~L}^{-1}$ yeast extract, and $50 \mathrm{gL}^{-1}$ glycerol ( $\mathrm{pH} 5.6$ ). All media were sterilized in an autoclave for $20 \mathrm{~min}$ at $121^{\circ} \mathrm{C}$.

Potato wastewater was obtained from the processing Line of PEPEES SA Company (Łomża, Poland) during the potato campaign in autumn 2015, after coagulating the proteins using thermal-acid coagulation technique. The wastewater was sterilized for further evaluation $\left(121^{\circ} \mathrm{C} / 0.1 \mathrm{MPa} / 20 \mathrm{~min}\right)$ (HiCLAVE HG-80 autoclave, HMC Europe), as we had detected the presence of aerobic spore bacilli, mold, and yeast spores. DPW was centrifuged to remove precipitates formed during sterilization $(3200 \times \mathrm{g} / 20 \mathrm{~min})$ (Eppendorf $5810 \mathrm{Cen}-$ trifuge), which was followed by the addition of glucose $\left(50 \mathrm{gL}^{-1}\right)$, lactose $\left(50 \mathrm{~g} \mathrm{~L}^{-1}\right)$, or glycerol $\left(50 \mathrm{gL}^{-1}\right)$. The $\mathrm{pH}$ was adjusted to 5.6 using $0.1 \mathrm{M} \mathrm{NaOH}$ and the entire mixture was sterilized according to the procedure described above. The experimental media supplemented with glucose, lactose, and glycerol will be, respectively, referred to as DPWGlc, DPWLac, and DPWGly in future of this manuscript.

2.3.2. Preparation of Inoculum. Fifty-milliliter liquid YPD medium was inoculated with the selected strain from the slant cultures in round flat-bottom flask. The cultures were grown at $28^{\circ} \mathrm{C}$ (MaxQ 4000 , Barnstead) for $24 \mathrm{~h}$ on a reciprocating shaker with a frequency of 200 cycles/min. The inoculum obtained by this method constituted material for inoculation of microculture in Bioscreen $\mathrm{C}$ system and for proper culture experiments.

2.3.3. Screening of the Growth with the Use of Bioscreen $C$ System. Growth of strains was analyzed in the experimental media using Bioscreen C apparatus (Oy Growth Curves Ab Ltd., Finland). Briefly, $270 \mu \mathrm{L}$ of the medium (control and experimental) and $30 \mu \mathrm{L}$ of inoculum (about $1 \times 10^{5} \mathrm{cfu} \mathrm{cm}^{-3}$ ) were introduced to one microwell on the Honeycomb plate. The cultures were grown at $28^{\circ} \mathrm{C}$ under constant shaking, and their optical density (OD) was recorded for every $15 \mathrm{~min}$ $\left(\lambda_{420-580 \mathrm{~nm}}\right)$. Suitable maximum growth rates $\left(\mu_{\max }\right)$ and generation time were determined after preparing the growth curves. The coefficient of specific growth rate $(\mu)$ in time $(t)$ was calculated using the formula, $\mu(t)=\left(\ln \mathrm{OD}_{f}-\right.$ $\left.\ln \mathrm{OD}_{i}\right) /\left(t_{f}-t_{i}\right)$, where $\mathrm{OD}_{f}$ is final OD in the log phase, $\mathrm{OD}_{i}$ is initial OD in the log phase, $t_{f}$ is time of log-phase termination, and $t_{i}$ is time of log-phase onset.

2.3.4. Experimental Culture Conditions. All cultures were grown in $500 \mathrm{~mL}$ flasks. Media $(90 \mathrm{~mL})$ were inoculated with inoculum constituting $10 \%$ of the culture volume. The cultures were incubated for $96 \mathrm{~h}$ at $28^{\circ} \mathrm{C}$ on SM-30 Control (Buehler, Germany) shaker at a frequency of 200 cycles $\mathrm{min}^{-1}$. Each culture variant was grown in triplicate.

2.3.5. Examinations of Cell Morphology. The examination of the shape and size of the cells was conducted using the microscope (Opta-Tech 300, Poland) and microscopic camera (Opta-Tech) integrated OptaWiew7 (V:2.1.) software. The length (longer dimension), width (shorter dimension), and surface of minimum of 100 cells were measured.

2.3.6. Determination of $O D$. OD of culture was determined after centrifugation of $2 \mathrm{~mL}$ of culture $(1610 \times \mathrm{g} / 5 \mathrm{~min})$ (Eppendorf mini Spin plus). The supernatant was decanted, and the biomass precipitate was suspended in $2 \mathrm{~mL}$ of distilled water. OD was measured spectrophotometrically at a wavelength of $600 \mathrm{~nm}$ against distilled water as blank (UV - 1800 UV/VIS, RayLeigh Analytical Instrument).

2.3.7. Determination of Biomass Yield. To determine the biomass yield after completion of incubation, postculture fluid was transferred to a dried and weighed extraction 
thimble and centrifuged $(2000 \times \mathrm{g} / 20 \mathrm{~min})$ (Eppendorf Centrifuge 5804R). Then, the supernatant was decanted and the precipitate containing the biomass was washed twice with sterile distilled water followed by drying until a constant weight was achieved at $105^{\circ} \mathrm{C}$ (SML 32/250 Zelmed drier, Poland). Biomass yield was expressed in terms of grams of dry yeast per liter of culture medium (g d.w. $\mathrm{L}^{-1}$ medium). The biomass concentration at the beginning of culture was about 0.4 g d.w. $\mathrm{L}^{-1}$ medium for each strain.

2.3.8. Lipid Analysis. After culturing, yeast biomass was centrifuged $\left(2000 \times \mathrm{g} / 4^{\circ} \mathrm{C} / 10 \mathrm{~min}\right)$ (Eppendorf Centrifuge $5804 \mathrm{R})$. Then, it was rinsed twice with sterile deionized water and then dried at $80^{\circ} \mathrm{C}$ until a constant weight was achieved. The biomass yield was expressed in terms of grams dry yeast per liter of the culture medium ( $\mathrm{g}$ d.w. $\mathrm{L}^{-1}$ medium). The lipid content in yeast biomass was determined according to the method of Bligh and Dyer and modified based on Zhang et al. [37], which involves lipid extraction using chloroform and methanol. Lipid content was expressed as $\%$ of cell dry weight (\% CDW).

(1) Relative Composition of Fatty Acids. Fatty acid methyl esters were determined using the gas chromatographic technique coupled with flame ionization detector (GC-FID TRACE 1300, Thermo Scientific); methylation of fatty acids to methyl esters was performed prior to GC-FID analysis. Lipids were extracted using chloroform/methanol mixture and then the lipids were dissolved in hexane. Then, methylation of the lipid phase dissolved in hexane was performed using potassium methoxide $\left(37^{\circ} \mathrm{C}, 12 \mathrm{~h}^{-1}\right)$. The hexane layer was collected and subjected to chromatographic separation using Rtx-2330 column $(60 \mathrm{~m} \times 0.25 \mathrm{~mm} \times 0.2 \mu \mathrm{m})$. The samples were injected at $250^{\circ} \mathrm{C}$ (split $1: 10$ ). The following gradient of oven temperatures was applied: $50^{\circ} \mathrm{C}(3 \mathrm{~min})$ and $3^{\circ} \mathrm{C}$ $\mathrm{min}^{-1}$ temperature increase to $250^{\circ} \mathrm{C}(5 \mathrm{~min})$. The separation was conducted with a steady flow of carrier gas through the capillary column $\left(1.6 \mathrm{~cm}^{3} \mathrm{~min}^{-1}\right)$. The temperature of FID detector was set at $260^{\circ} \mathrm{C}$. The methyl esters were identified based on the retention times of standards present in the mixture (GLC $461 \mathrm{Nu}$-Chek Prep. Inc. USA).

\subsection{The Deproteinated Potato Wastewater Characterization}

2.4.1. The Selected Elemental Content. The dry matter content in DPW was determined by gravimetric method $\left(105^{\circ} \mathrm{C}\right.$, $24 \mathrm{~h}$, SML 32/250, Zetmet). The nitrogen content was determined by the Kjeldahl method (Büchi Digestion Unit K-435, Büchi Distillation Unit K-355) [16]. The elements that were estimated in DPW were $\mathrm{P}, \mathrm{K}, \mathrm{Na}, \mathrm{Ca}, \mathrm{Mg}$, and $\mathrm{Mn}$ using inductively coupled plasma atomic emission spectroscopy (ICP-AES) (Thermo iCAP 6500). For this, the samples of deproteinated potato wastewater $(2 \mathrm{~mL})$ were mineralized (Buchi Digestion Unit K-435) using a mixture of nitric acid $(5 \mathrm{~mL})$ and perchloric acid $(2 \mathrm{~mL})$. After mineralization, the digested mixture was transferred by purging hydrochloric acid to $25 \mathrm{~mL}$ flasks and then filling them with deionized water. The wavelength for individual element was Ca: 315.8, 373.6, and $422.6 \mathrm{~nm}$; K: 766.4 and 769.8; Mg: 279.5, 280.2,
285.2, and 382.9; Na: 588.9 and 589.5; and P: 177.4, 178.2, and 213.6. The results were expressed in terms of grams of element adjusted to a one liter of the culture medium. The measurements of the selected elements were also performed for synthetic YPGlc medium.

2.4.2. Electrophoretic Analysis. Proteins were separated on a polyacrylamide gel electrophoresis under denaturing conditions (SDS-PAGE) using 3\% thickening silica gel and $12 \%$ separating gel. Protein was denatured in a temperature range of $90-100^{\circ} \mathrm{C}$ for $5 \mathrm{~min}$ with concurrent shaking (Eppendorf Thermomixer Comfort, Germany). Then, electrophoresis was performed using a Mini Protean ${ }^{\circledR} 3$ Bio-Rad device at constant current of $20 \mathrm{~mA}$ (voltage is $200 \mathrm{~V}$ ) in 1x Tris-glycine buffer with a $\mathrm{pH}$ of 8.3. An appropriate molecular weight marker (Precision Plus Protein Dual Xtra Standards, BioRad) was used to determine the mass of protein fractions. For visualization, the gel was stained with Coomassie Brilliant Blue R-250. Electrophoretically separated proteins were documented using a gel recording system (GelDoc 2000, BioRad, France). Proteins were analyzed using the Quantity One version 4.2.1 (France) computer program [38].

2.5. Statistical Analysis of the Results. All values are mean of three separate experiments. The results obtained were statistically analyzed using the STATISTICA V.10 program (StatSoft Polska Sp. z o.o., Krakow, Poland). Analysis of variance (ANOVA) was performed using Tukey's test at $\alpha=$ 0.05 level of significance.

2.6. Calculation of Biodiesel Properties. The properties of fatty acids methyl-esters, namely, unsaturation degree (UN), cetane number (CN), length of chain (LC), low caloric value $(\mathrm{LCV})$, flash point $(\mathrm{FP})$, and viscosity $(\mu)$ were estimated based on the following equations:

$$
\mathrm{UN}=\frac{\left(1 \%_{\mathrm{MU}}+2 \%_{\mathrm{DU}}+3 \%_{\mathrm{TU}}\right)}{100}
$$

(see [39]),

$$
\mathrm{CN}=\Sigma X_{\mathrm{ME}} \mathrm{CN}_{\mathrm{ME}}
$$

(see [40]),

$$
\begin{aligned}
\mathrm{LC}= & \mathrm{R}\left(n \mathrm{C}_{n} c_{n}\right) \\
\mathrm{LCV}= & 29385,4+486,866 \mathrm{LC}-387,766 \mathrm{UD}\left[\mathrm{kJ} \mathrm{kg}^{-1}\right] \\
\mu= & -1,8327+0,209794 \mathrm{LC}+0,738911 \mathrm{UD} \\
& +0,0166791 \mathrm{LC}^{2}-0,16336 \mathrm{LCUD} \\
& +0,335547 \mathrm{UD}^{2}\left[\mathrm{~mm}^{2} \mathrm{~s}^{-1}\right]
\end{aligned}
$$

(see [39]),

where

$n \mathrm{C}_{n}$ is the number of carbon atoms of each fatty acids, $c_{n}$ is the percentage of weight of each methyl ester containing this fatty acids, 


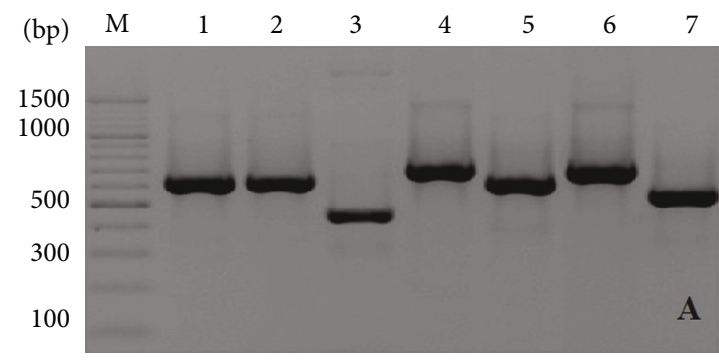

(a)

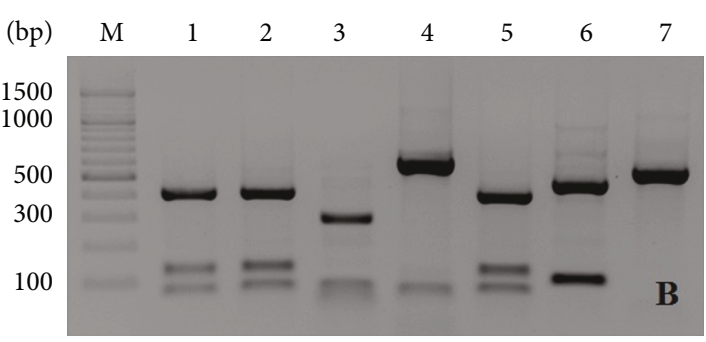

(b)

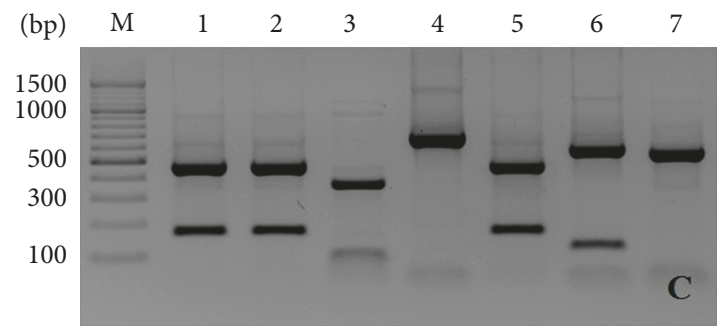

(c)

FIGURE 1: (a) Electrophoretic separation of PCR amplification products on $2 \%$ agarose gel (M-molecular marker; 1 -Debaryomyces hansenii 1; 2-Debaryomyces hansenii IG II; 3-Candida inconspicua IG 11; 4-Kluyveromyces marxianus IG 16; 5-Debaryomyces hansenii IG 01; 6-Kazachstania unispora IG 16; 7-Zygotorulaspora florentina IG 12). (b) Electrophoretic separation of yeast DNA digested with restriction enzyme HaeIII (M-molecular marker; 1-Debaryomyces hansenii 1; 2-Debaryomyces hansenii IG II; 3-Candida inconspicua IG 11; 4Kluyveromyces marxianus IG 16; 5-Debaryomyces hansenii IG 01; 6-Kazachstania unispora IG 16; 7-Zygotorulaspora florentina IG 12). (c) Electrophoretic separation of yeast DNA digested with restriction enzyme RsaI (M-molecular marker; 1-Debaryomyces hansenii 1; 2-Debaryomyces hansenii IG II; 3-Candida inconspicua IG 11; 4-Kluyveromyces marxianus IG 16; 5-Debaryomyces hansenii IG 01; 6-Kazachstania unispora IG 16; 7-Zygotorulaspora florentina IG 12).

$\%_{\mathrm{MU}}$ is the percentage of weight of monounsaturated methyl esters,

${ }^{\mathrm{DU}}$ is the percentage of weight of di-unsaturated methyl esters,

$\%_{\mathrm{TU}}$ is percentage of weight of tri-unsaturated methyl esters,

$X_{\mathrm{ME}}$ is the weight percentage of each methyl ester,

$\mathrm{CN}_{\mathrm{ME}}$ is the cetane number of individual methyl ester.

\section{Results}

3.1. Identification of Kefir Yeast Isolates. In this study, the degree of identification of yeast isolates based on API 20 AUX system was high, which was found to be more than 99\%. This allowed the identification of seven strains from the isolates. The species identified were as follows: Candida guilliermondii 1, Candida guilliermondii 2, Candida famata, Candida kefyr, Candida inconspicua, Saccharomyces cerevisiae, and Cryptococcus albidus (Table 1). Limited identification opportunities of API 20 AUX system prompted us to perform the identification based on molecular tools. PCR analysis of the reaction products using ITS1 and ITS4 primers and restrictive cleavage using enzymes HaeIII and RsaI, as well as sequencing, were the basis for their identification (Table 1). Application of ITS1 and ITS4 primers to amplify DNA fragments of kefir yeast isolates causes an intensification of PCR products of about 460-700 bp (Figure 1(a)). The applied primers ITS1 and ITS4 caused strengthening of the amplification product by a value of about $640 \mathrm{bp}$ in case of three isolates of Debaryomyces hansenii. In case of C. inconspicua IG 11, Kluyveromyces marxianus IG 1, and Zygotorulaspora florentina IG 12, the strengthening of the product after DNA fragment amplification was 460, 700, and $600 \mathrm{bp}$, respectively (Table 2 ).

We found, after electrophoretic separation of the PCR products as a result of obtaining of determined length of amplicons and the use of restriction enzyme HaeIII, that the molecular weights of the PCR products for all strains of $D$. hansenii were 410, 140, and $90 \mathrm{bp}$, respectively (Figure 1(b)). Different length restriction fragments of $C$. inconspicua IG 11 (290, 90, and 80 bp), K. marxianus IG 1 (620 and 80 bp), and Kazachstania unispora IG 16 (550 and 130 bp) were obtained as a result of DNA digestion of the amplification products using restriction enzyme HaeIII. In case of three isolates of $D$. hansenii, two bands with 450 and $190 \mathrm{bp}$ were obtained as a result of digestion using RsaI enzyme (Figure 1(c)). However, in case of $Z$. florentina IG 12, DNA digestion using HaeIII restriction enzyme did not result in any new fragment, whereas digestion using RsaI enzyme resulted in two fragments with 520 and $80 \mathrm{bp}$ (Table 2). Table 1 shows the partial and complete gene sequences for 18S rRNA ITS1, 5.8S rRNA, ITS2, and 28S rRNA that were deposited and analyzed in GenBank, including their accession number. Figure S1, in Supplementary Material available online at https://doi.org/10.1155/2017/6061042, presents the differences between the yeast isolates using the phylogenetic tree [41]. 
TABLE 1: Results of an identification of kefir yeast isolates using API 20 AUX and genetic analysis.

\begin{tabular}{|c|c|c|c|}
\hline $\begin{array}{l}\text { API name isolate } \\
\text { identification }\end{array}$ & Origin & bp & $\begin{array}{l}\text { Name of isolate } \\
\text { GenBank number }\end{array}$ \\
\hline $\begin{array}{l}\text { Candida } \\
\text { inconspicual } \\
\text { Candida } \\
\text { krusei } \\
99.5 \%\end{array}$ & $\begin{array}{l}1 \text { caaaaaacaa aactttcaac aacggatctc ttggttctcg catcgatgaa gagcgcagcg } \\
61 \text { aaatgcgata cctagtgtga attgcagcca tcgtgaatca tcgagttctt gaacgcacat } \\
121 \text { tgcgccctct ggtattccgg agggcatgcc tgtttgagcg tcgtttcctt cttgcttgcg } \\
181 \text { agcagaaatg ggggggccet ggcattgggg ccgctctgaa aagaaacgtt gcgggcgaag } \\
241 \text { cgaactatga gtaggacgct tggccgccga acttaataca taagctcgac ctcaaatcag } \\
301 \text { gtaggaatac ccgctgaact taagca }\end{array}$ & 326 & $\begin{array}{c}\text { Candida inconspicua IG } 11 \\
\text { LC164191.1 }\end{array}$ \\
\hline $\begin{array}{l}\text { Candida } \\
\text { guilliermondii } 1 \\
99.1 \%\end{array}$ & $\begin{array}{l}1 \text { acttttgctt tggtctggac tagaaatagt ttgggccaga ggtttactga actaaacttc } \\
61 \text { aatatttata ttgaattgtt atttatttaa ttgtcaattt gttgattaaa ttcaaaaaat } \\
121 \text { cttcaaaact ttcaacaacg gatctcttgg ttctcgcatc gatgaagaac gcagcgaaat } \\
181 \text { gcgataagta atatgaattg cagattttcg tgaatcatcg aatctttgaa cgcacattgc } \\
241 \text { gccctctggt attccagagg gcatgcctgt ttgagcgtca tttctctctc aaaccttcgg } \\
301 \text { gtttggtatt gagtgatact cttagttgaa ctaggcgttt gcttgaaatg tattggcatg } \\
361 \text { agtggtactg gatagtgcta tatgactttc aatg }\end{array}$ & 394 & $\begin{array}{l}\text { Debaryomyces hansenii } 1 \\
\text { LC126697.1 }\end{array}$ \\
\hline $\begin{array}{l}\text { Candida } \\
\text { famata } \\
99.9 \%\end{array}$ & $\begin{array}{l}1 \text { gaacttttgc tttggtctgg actagaaata gtttgggcca gaggtttact gaactaaact } \\
61 \text { tcaatattta tattgaattg ttatttattt aattgtcaat ttgttgatta aattcaaaaa } \\
121 \text { atcttcaaaa ctttcaacaa cggatctctt ggttctcgca tcgatgaaga acgcagcgaa } \\
181 \text { atgcgataag taatatgaat tgcagatttt cgtgaatcat cgaatctttg aacgcacatt } \\
241 \text { gcgecctctg gtattccaga gggcatgcct gtttgagcgt catttctctc tcaaaccttc } \\
301 \text { gggtttggta ttgagtgata ctcttagttg aactaggcgt ttgcttgaaa tgtattggca } \\
361 \text { tgagtggtac tggatagtgc tatatgactt tcaatgtatt aggtttatcc aactcgttga } \\
421 \text { atagtttaat ggtatatttc tcg }\end{array}$ & 443 & $\begin{array}{c}\text { Debaryomyces hansenii IG } 01 \\
\text { LC164190.1 }\end{array}$ \\
\hline $\begin{array}{l}\text { Candida } \\
\text { guilliermondii } 2 \\
99.1 \%\end{array}$ & $\begin{array}{l}1 \text { cttttgcttt ggtctggact agaaatagtt tgggccagag gtttactgaa ctaaacttca } \\
61 \text { atatttatat tgaattgtta tttatttaat tgtcaatttg ttgattaaat tcaaaaaatc } \\
121 \text { ttcaaaactt tcaacaacgg atctcttggt tctcgcatcg atgaagaacg cagcgaaatg } \\
181 \text { cgataagtaa tatgaattgc agattttcgt gaatcatcga atctttgaac gcacattgcg } \\
241 \text { ccctctggta ttccagaggg catgcctgtt tgagcgtcat ttctctctca aaccttcggg } \\
301 \text { tttggtattg agtgatactc ttagttgaac taggcgtttg cttgaaatgt attggcatga } \\
361 \text { gtggtactgg atagtgctat atgactttca atgtattagg tttatccaac tcgttgaata } \\
421 \text { gtttaa }\end{array}$ & 426 & $\begin{array}{l}\text { Debaryomyces hansenii IG II } \\
\text { LC164187.1 }\end{array}$ \\
\hline $\begin{array}{l}\text { Saccharomyces } \\
\text { cerevisiae } \\
61.0 \%\end{array}$ & $\begin{array}{l}1 \text { gccgaaccag cgcttaattg cgcggtttgg tgggtctctg tagctcagta gcactattac } \\
61 \text { acactgtgga gattttataa ttctttgcat gcttctttgg gcagcttcgg cagcccagag } \\
121 \text { gtaacaaaca caaacaactt tgtaatattt ttaacccagt caaaaccaga attccagaaa } \\
181 \text { gatttatctt tttgtaatat tataacaaat attcaaaact ttcaacaacg gatctcttgg } \\
241 \text { ttctcgcatc gatgaagaac gcagcgaaat gcgatacgta atgtgaattg cagaattccg } \\
301 \text { tgaatcatcg aatctttgaa cgcacattgc gccccttg }\end{array}$ & 338 & $\begin{array}{c}\text { Kazachstania unispora IG } 16 \\
\text { LC164188.1 }\end{array}$ \\
\hline $\begin{array}{l}\text { Candida kefyr } \\
99.9 \%\end{array}$ & $\begin{array}{l}1 \text { ttctcatcct aaacacaatg gagttttttc tctatgaact acttccctgg agagctcgtc } \\
61 \text { tctccagtgg acataaacac aaacaatatt ttgtattatg aaaaactatt atactataaa } \\
121 \text { atttaatatt caaaactttc aacaacggat ctcttggttc tcgcatcgat gaagaacgca } \\
181 \text { gcgaattgcg atatgtattg tgaattgcag attttcgtga atcatcaaat ctttgaacgc } \\
241 \text { acattgcgcc ctctggtatt ccagggggca tgcctgtttg agcgtcattt ctctctcaaa } \\
301 \text { cctttgggtt tggtagtgag tgatactcgt ctcgggttaa cttgaaagtg gctagccgtt } \\
361 \text { gccatctgcg tgagcagggc tgcgtgtcaa gtctatggac t }\end{array}$ & 401 & $\begin{array}{c}\text { Kluyveromyces marxianus IG } 1 \\
\text { LC126698.1 }\end{array}$ \\
\hline $\begin{array}{l}\text { Cryptococcus } \\
\text { albidus } \\
99.1 \%\end{array}$ & $\begin{array}{l}1 \text { ctgacacata cacacagtgg agatatattc tttcttcttc ttcttctttg ggggacggcg } \\
61 \text { gtttgcgctg ctgctccag aatgaaaaa cacaaacaac ttttgtatta ttacagatgt } \\
121 \text { caaaacacaa aacaaaatac caaaactttc aacaacggat ctcttggttc tcgcatcgat } \\
181 \text { gaagaacgca gcgaaatgcg atacgtaatg tgaattgcag aattccgtga atcatcgaat } \\
241 \text { ctttgaacgc acattgcgcc ccttggtatt ccagggggca tgcctgtttg agcgtcattt } \\
301 \text { ccttctcaaa cacttgtgtt tggtagtgag tgatactctg taacatggga gttagcttga } \\
361 \text { aattgagagc ccatgggetg ctctgctgag gcggaagtcg tgctaggtaa caccaactcg } \\
421 \text { acgcaacgca ttcggctgga cgcagctccg gcgaacaaac acatcaacgc ttgacctcaa } \\
481 \text { atca }\end{array}$ & 484 & $\begin{array}{l}\text { Zygotorulaspora florentina IG } \\
12\end{array}$ \\
\hline
\end{tabular}

API: Api 20 AUX tests; bp: base pairs. 
TABLE 2: Summary of sizes in base pairs of the PCR products and the restriction fragments of yeast DNA.

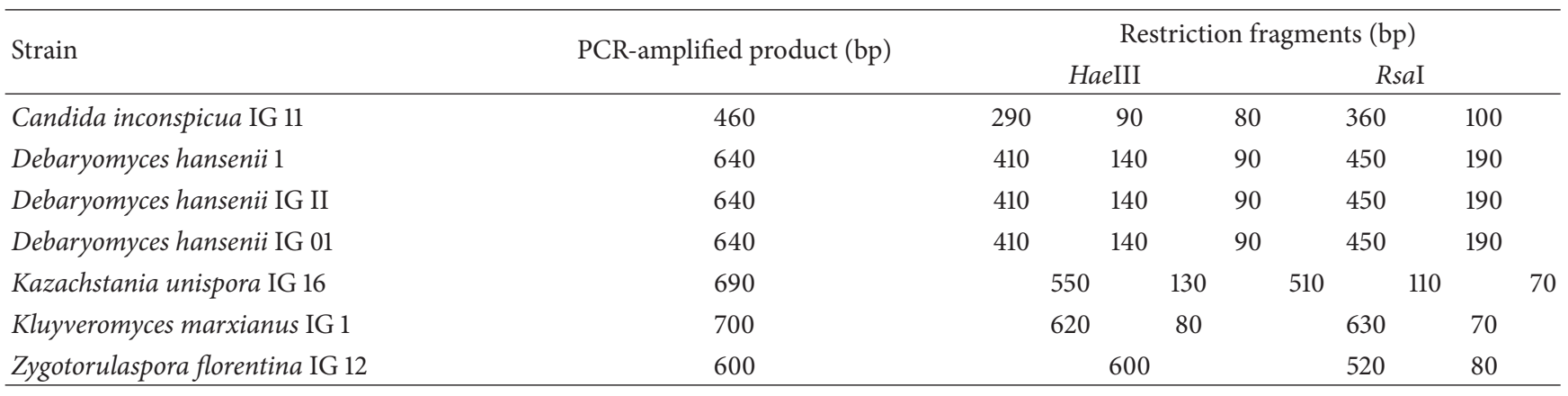

bp: base pairs; PCR: polymerase chain reaction.

3.2. Morphology and Cell Dimensions of Kefir Yeast Isolates. All isolated yeast strains formed colonies of white to various shadows of cream and beige color on the solid medium and were mostly characterized by shape specific for yeasts. Strains $K$. marxianus IG 1, Z. florentina IG 12, K. unispora IG 16, and three strains of $D$. hansenii formed glossy colonies. In liquid media, most of the examined strains were growing in the whole medium volume (diffusion growth) during stationary culture. A ring on liquid medium surface was formed by $D$. hansenii 1 and C. inconspicua IG 11 strains.

The lowest dimensions in YPD medium (Table S1) were characteristic for the cells of both $D$. hansenii IG II strains. Cells, longer than $3 \mu \mathrm{m}$, belonged to C. inconspicua IG 11 strain. The cell width of a particular strain was from 1.59 to $2.58 \mu \mathrm{m}$, and it is noteworthy that, in this case, the dispersion of the results was much lower than in the case of the length. The cell morphology closest to sphere was determined by definition of shape coefficient expressed as a ratio of cell length to its width. The value of shape coefficient for such cells should amount to 1 . The strains whose cells were of spherical shape included all $D$. hansenii strains and $Z$. florentina IG 12. The shape coefficient between 1 and 2 was for the following strains $K$. unispora IG 16, K. marxianus IG 1, and C. inconspicua IG 11. Their cell morphology can be described as oval or ellipsoidal.

3.3. Characteristics of DPW. The physicochemical parameters of wastewater obtained from the process line after deproteinization stage shows Table 3 . The dry matter content in $100 \mathrm{~cm}^{3}$ exceeds $3.3 \mathrm{~g}$, and the amount of reducing sugars was found to be $0.4 \mathrm{~g}$. An average nitrogen level was found to

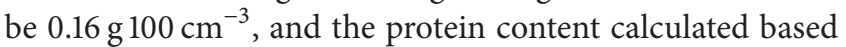
on nitrogen level was found to be $1 \mathrm{~g} 100 \mathrm{~cm}^{-3}$. The wastewater contained large amounts of potassium (over $0.4 \%$ ). The electrophoretic analysis of wastewater did not confirm the presence of proteins of a weight lower than $250 \mathrm{kDa}$ (Figure S2).

3.4. Growth of Kefir Yeast in the Examined Media. Isolated yeast strains were able to assimilate the examined carbon sources. The cells grew the fastest in the glucosesupplemented media with peptone and yeast extract. The use of lactose and glycerol significantly reduced the specific growth rate (Table S2). We observed that the growth of the yeast isolates in media with wastewater was characterized by
TABLE 3: Composition of deproteinated potato wastewater used in this study.

\begin{tabular}{lcc}
\hline Parameter & Unit & $\begin{array}{c}\text { Deproteinated potato } \\
\text { wastewater }\end{array}$ \\
\hline $\mathrm{pH}$ & & $4.9 \pm 0.1$ \\
\hline Dry substance & $\mathrm{g} \mathrm{d} . \mathrm{w} .100 \mathrm{~cm}^{-3}$ & $3.3260 \pm 0.0430$ \\
\hline Directly reducing sugars & & $0.4400 \pm 0.0032$ \\
Nitrogen & & $0.1620 \pm 0.0062$ \\
Potassium & $\mathrm{g} 100 \mathrm{~cm}^{-3}$ & $0.4137 \pm 0.0320$ \\
Phosphorus & & $0.0333 \pm 0.0020$ \\
Magnesium & & $0.0236 \pm 0.0035$ \\
Calcium & & $0.0100 \pm 0.0010$ \\
\hline Sodium & $\mathrm{mg} 100 \mathrm{~cm}^{-3}$ & $6.063 \pm 0.051$ \\
Manganese & & $0.181 \pm 0.011$ \\
\hline
\end{tabular}

an extended lag-phase (data not shown) and lower specific growth rate compared to the control YP medium. Supplementation of lactose and glycerol in these media reduced the specific growth rate compared to glucose. Only in case of D. hansenii 1 and D. hansenii IG 01, glycerol in the medium increased the proliferation rate of the cells.

The highest biomass yield (in the range of $13.5-14.8 \mathrm{~g} \mathrm{~L}^{-1}$ ) was observed in the YPGlc medium in case of three strains of Debaryomyces genus and Z. florentina IG 12 (Table 4). The lowest biomass yield $\left(11 \mathrm{~g} \mathrm{~L}^{-1}\right)$ in the control media (YP) with glucose and lactose was noted for K. unispora IG 16 culture. The differences in fertility of strains depending on the tested carbon source with wastewater were much smaller, for example, in the media with lactose, average yields of examined strains' biomass ranged from 10.9 to $12.4 \mathrm{~g} \mathrm{~L}^{-1}$ and in case of glycerol from 10.3 to $11 \mathrm{~g} \mathrm{~L}^{-1}$. Biomass productivity did not reach the value of $0.2 \mathrm{~g} \mathrm{~L}^{-1} \mathrm{~h}^{-1}$ in any tested medium variant, both the control and the wastewater.

3.5. Intracellular Lipid Content. The highest lipid content after incubation in YP media with glucose was found in the biomass of $D$. hansenii 1 strain (CDW more than $46 \%$ after $96 \mathrm{~h}$ of culturing) (Figure 2). Fat content greater than $20 \%$, which is a feature of oleaginous microorganisms, was found in case of D. hansenii IG 01, C. inconspicua IG 11, Z. florentina 


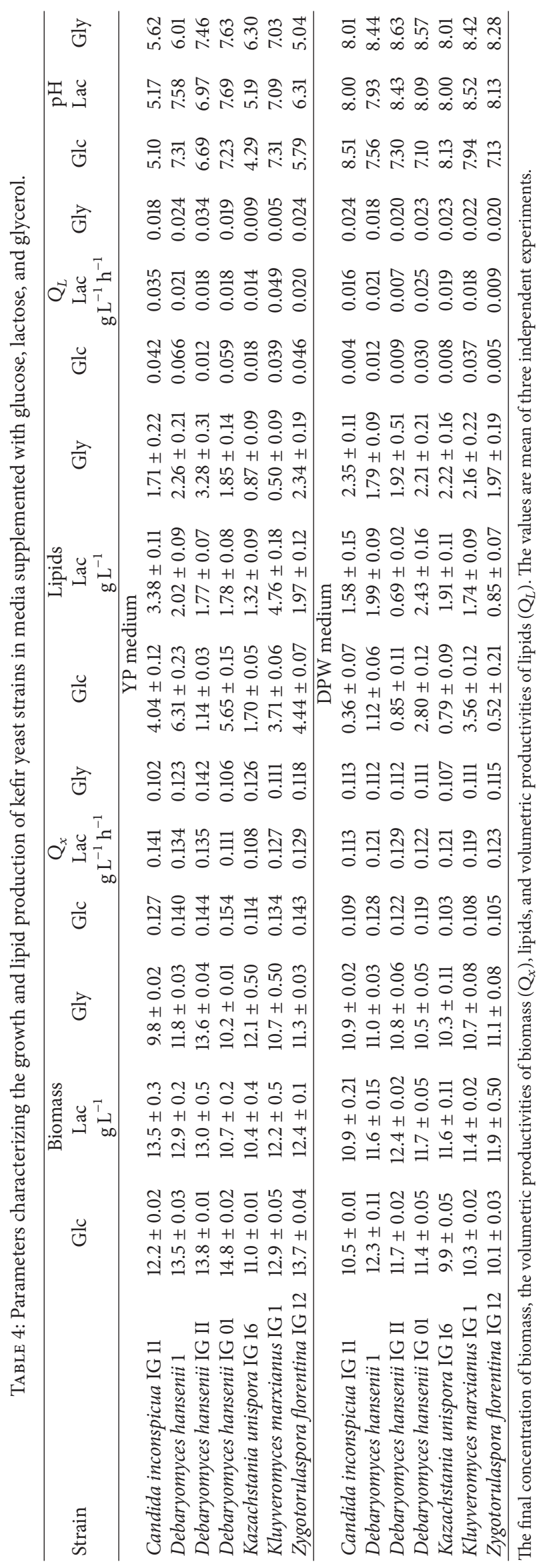




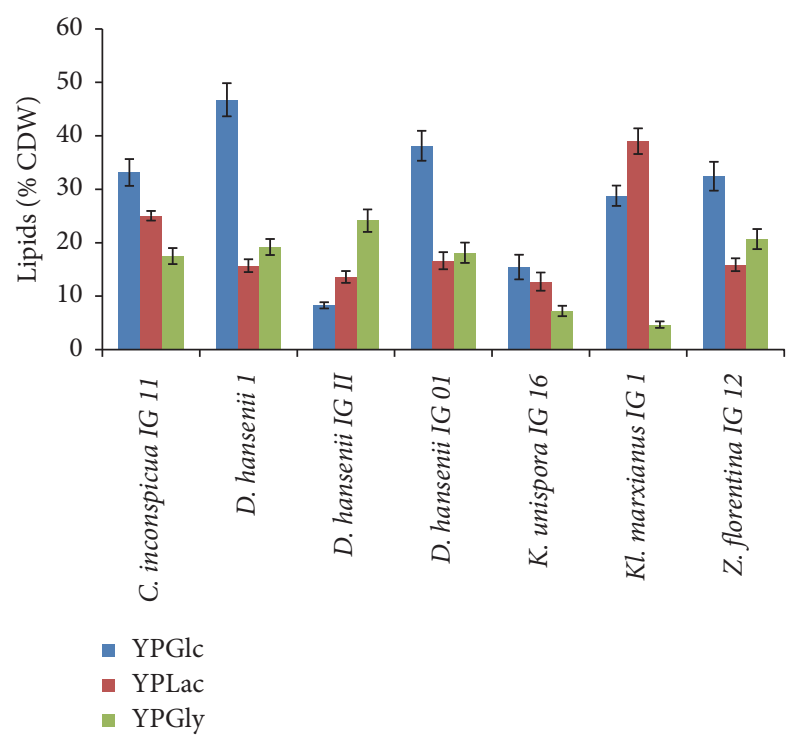

FIgure 2: Total lipid production (\% cell dry waste (CDW)) in kefir yeast biomass after culturing in YP media supplemented with glucose, lactose, and glycerol.

IG 12 , and $K$. marxianus IG 1 strains. Lower fat content was found in the same medium with lactose supplementation. The exception was K. marxianus strain, which accumulated 39\% of fats in dry weight. Glycerol, compared to glucose, in the medium with peptone and yeast extract, generally reduced lipid content in the group of examined strains. An exception was $D$. hansenii IG II strain, whose biomass after culturing in YPGly medium was characterized by lipid content more than $24 \%$. The volumetric yield of lipid biosynthesis in control media was the highest in the case of $D$. hansenii 1 , which was $6.31 \mathrm{~g} \mathrm{~L}^{-1}$, for $D$. hansenii IG 01 it was $5.65 \mathrm{~g} \mathrm{~L}^{-1}$, and for $Z$. florentina IG 12 it was $4.44 \mathrm{~g} \mathrm{~L}^{-1}$. In the media supplemented with glycerol, the highest volumetric yield was determined for D. hansenii IG II ( $\left.3.28 \mathrm{~g} \mathrm{~L}^{-1}\right)$ and, concurrently, it was the highest compared to other carbon sources (Table 4). Lactose profitably increased the ability of cells to biosynthesize lipids in case of $K$. marxianus IG 1 and D. hansenii IG II strains.

Lipid content in dry biomass after the culturing in DPWGly medium exceeded $20 \%$ for C. inconspicua, D. hansenii IG 01, K. unispora IG16, and $K$. marxianus IG I strains (Figure 3). In the latter two strains, it was higher than the content in biomass after culturing in YP medium. Compared to the other carbon source, glycerol profitably affected the yield of lipids synthesis in the biomass of $K$. unispora IG $16, D$. hansenii IGII, C. inconspicua IG 11 , and Z. florentina IG 12 obtained after culturing in medium with the wastewater. Similar pattern was found for the volumetric $\left(Q_{L}\right)$ yield of lipids (Table 4). The lactose in DPW medium, compared to YP medium, significantly increased lipid content in the biomass of $D$. hansenii IG 01 and K. unispora. Wastewater as a source of nitrogen significantly reduced lipid content in the biomass of $C$. inconspicua, D. hansenii IG II, K. marxianus, and Z. florentina.

The use of DPW medium and glucose as carbon source revealed major differences in the ability of the examined strains for lipids biosynthesis. The share of this component higher than $20 \% \mathrm{~g}^{-1}$ d.w. biomass was only noted for $D$. hansenii IG 01 and K. marxianus IG I (Figure 3). Lipid content in the biomass of other strains was lower and did not exceed $10 \%$. The highest volumetric yield was noted for $K$. marxianus (3.56 $\left.\mathrm{g} \mathrm{L}^{-1}\right)$ and D. hansenii IG 01 strains $\left(2.80 \mathrm{~g} \mathrm{~L}^{-1}\right)$. It should be noted that the values were significantly lower than those achieved for the strains in media with yeast extract and peptone. Thus, the comparison of the volumetric yield of fats biosynthesis in control YP media with glucose and in experimental media with wastewater is favorable for the control medium.

Based on these findings, we can conclude that lipid content in d.w. of the examined yeast biomass was dependent on the duration of the culture, and, in all variants of the examined media, the share of this intracellular component increased after $72 \mathrm{~h}$ (Figure 3 ).

3.6. $\mathrm{pH}$ Changes. The initial $\mathrm{pH}$ of all media was 5.6. Cultures of examined yeast strains in all variants of media, experimental and control, caused significant changes in $\mathrm{pH}$ (Table 4). During the culture of yeast strains, the $\mathrm{pH}$ value of YP medium supplemented with glucose was found between 5.1 (C. inconspicua) and 7.31 (K. marxianus IG 1). In the YPLac, $\mathrm{pH}$ was in the range of 5.17-7.69, and, using glycerol, it was in the range of 5.04-7.63. Alkalization during culturing was observed for all strains in the experimental DPW media. The highest $\mathrm{pH}$ values (8.01-8.63) after $96 \mathrm{~h}$ were noted for the medium with wastewater supplemented with glycerol.

3.7. Fatty Acids Composition. The results of fatty acid profile after culturing yeast isolates in control (YPD) media supplemented with glucose are presented in Table 5. All examined yeast isolates demonstrated a large share of C18 fatty acids, among which oleic acid (C18:1 cis-9) was predominant. Its greatest share (more than 60\%) was found in lipids extracted from $D$. hansenii IG 01 biomass. A small amount of C18 fatty acids was found in the lipids of $K$. unispora strain; there was no C18:2 (linoleic acid) detected. In addition, this strain was characterized by the largest share of palmitoleic acid (C16:1) (more than 39\% for the YPGlc medium) and arachidonic acid (C20:4 n-6) and showed the presence of dihomo-gamma-linolenic acid (DGLA; C20:3 n-6). Docosadienoic acid (C22:2) was only found in case of two strains, that is, K. unispora and Z. florentina. Alpha linolenic acid (ALA, C18:3 n-3) was detected in the biomass of almost all strains. The largest share of polyunsaturated fatty acids (PUFAs) for most examined strains was detected in the control media supplemented with glucose (Figure 4). YP media supplemented with glycerol, compared to glucose and lactose, resulted in an increase in the total monounsaturated fatty acids (MUFAs), which can be correlated with a decrease in the pool of saturated fatty acids (SFAs). An exception was D. hansenii IG 01 strain, because a significant increase in the total content of PUFA was noted during its culture in medium supplemented with glycerol. However, an effect of glycerol on total MUFA content $\left(\mathrm{mg} \mathrm{L}^{-1}\right)$ was no longer so evident. The lowest amount of C18:1 (less than 20\%) among all strains was determined in fat extracted from K. unispora 


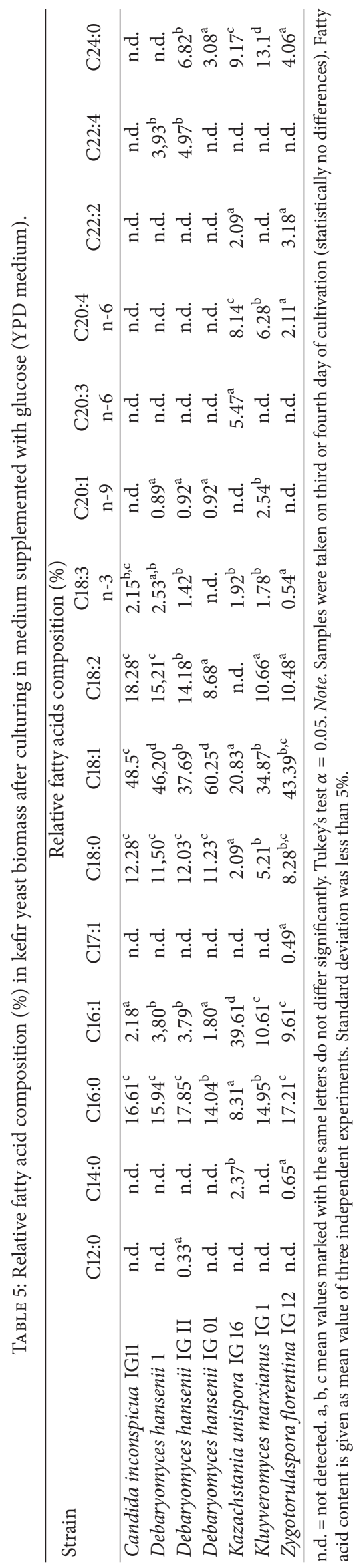



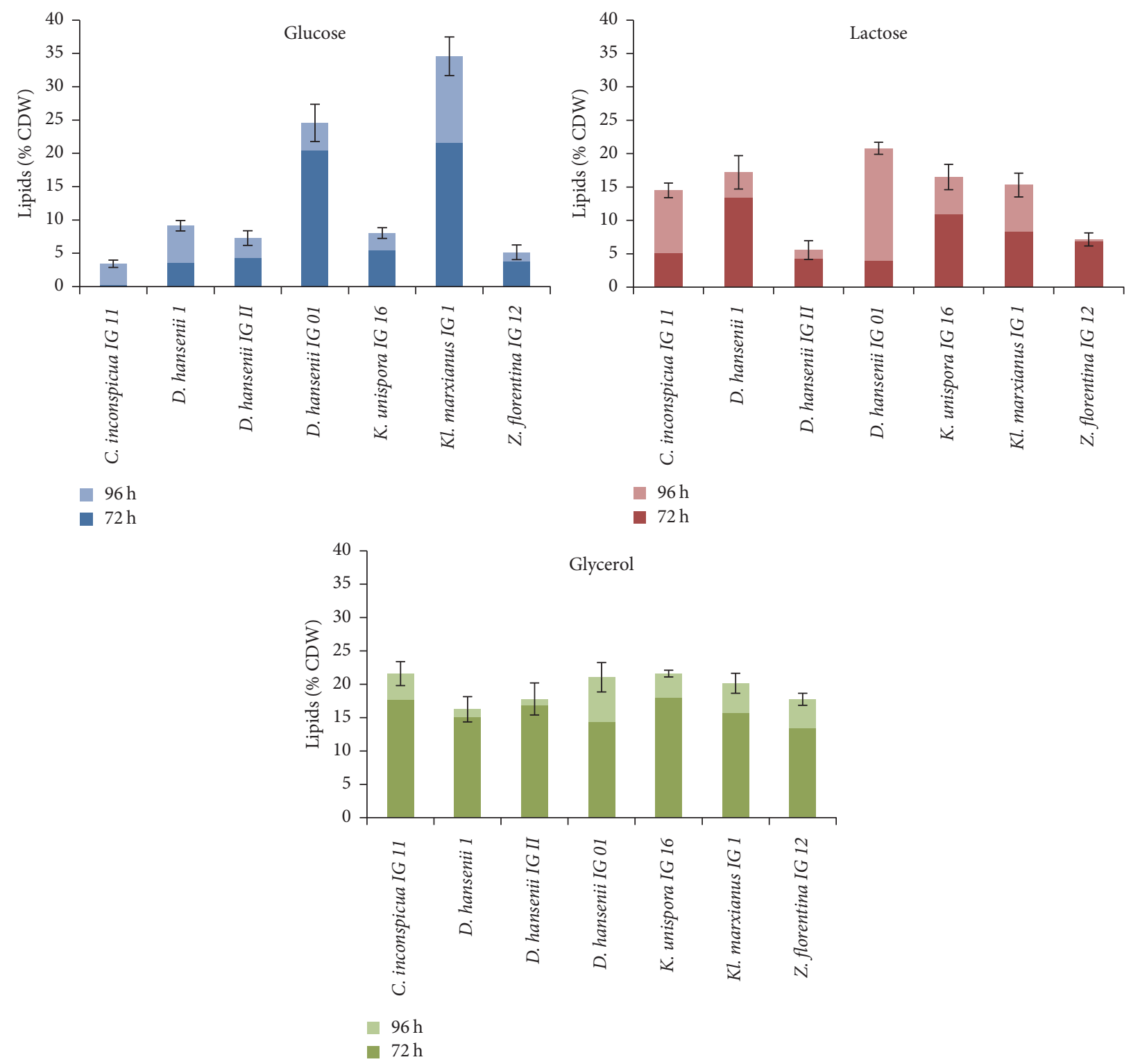

FIGURE 3: Effect of culture time on lipid content, expressed as \% cell dry waste (CDW): dark-colored bars cell dry waste-72 h and lightcolored bars-96 h, in deproteinated potato wastewater (DPW) media with glucose, lactose, and glycerol.

biomass obtained after culturing in DPWGlc, similar to YPGlc medium. Among other examined strains, the amount of oleic acid was significant and accounted for more than $45 \%$ of the total fatty acid content in the biomass of C. inconspicua, K. marxianus, and three strains of D. hansenii. K. unispora strain, regardless of carbon source, was characterized by the largest share of palmitoleic acid and the lowest share of PUFA.

The largest share of PUFA after culturing in experimental media with wastewater and glucose was found in the biomass of the three strains belonging to $D$. hansenii species (from 19.3 to $30.6 \% \mathrm{CDW}$ ). Regardless of the used carbon source, the culture of two isolates, C. inconspicua and K. unispora, in DPW media resulted in fat containing a significantly higher MUFA contribution. Such dependency has not been found for other strains (Figure 4).

\section{Discussion}

The molecular studies aimed at identification of general yeast species have emphasized either coding, that is, D1/D2 variable domains of a large subunit rDNA, or noncoding, that is, ITS regions of the DNA [42]. Databases of ITS sequences were available for molecular classification and identification of yeasts. Coding regions of the $18 \mathrm{~S}, 5.8 \mathrm{~S}$, and $28 \mathrm{~S}$ nuclear rRNA gene evolve slowly, are relatively conserved among fungi, and provide a molecular basis of establishing phylogenetic relationships $[43,44]$. For the three isolates of $D$. hansenii, the molecular weights of amplification products were similar to those published by Fujita et al. [45] and Połomska et al. [46]. Our results agree with the results published by Fujita et al. [45], after an application of the same primers 


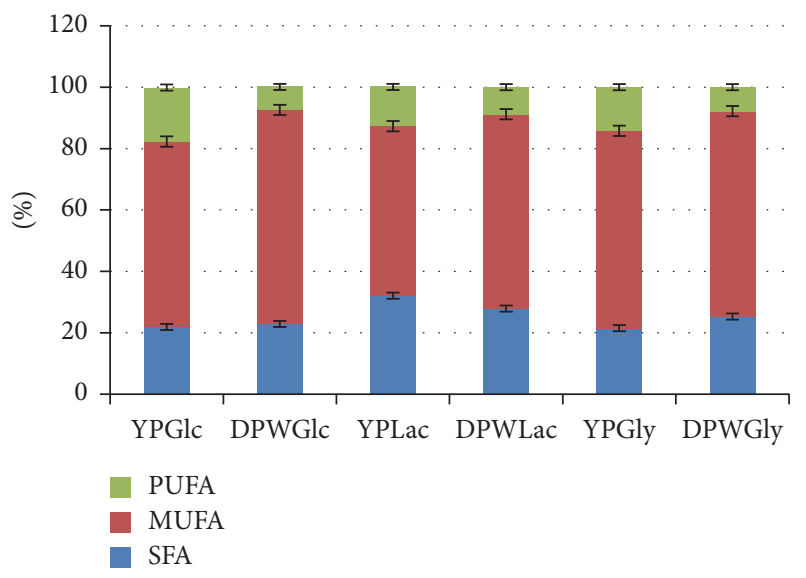

(a)

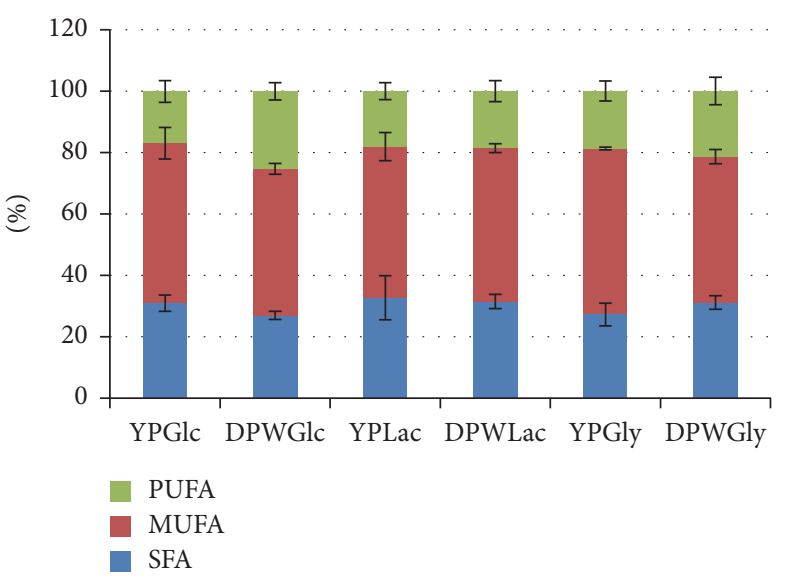

(b)

Figure 4: Total content of particular groups of fatty acids after culturing in all media supplemented with glucose, lactose, and glycerol on an example of Kazachstania unispora (a) and Debaryomyces hansenii (average values for all isolates) (b). SFA: saturated fatty acid; MUFA: monounsaturated; PUFA: polyunsaturated fatty acids; YPGlc: yeast peptone agar supplemented with glucose; YPLac: yeast peptone agar supplemented with lactose; YPGly: yeast peptone agar supplemented with glycerol; DPWGlc: deproteinated potato wastewater supplemented with glucose; DPWLac: deproteinated potato wastewater supplemented with lactose; DPWGly: deproteinated potato wastewater supplemented with glycerol. Note. Tukey's test, $\alpha=0.05$.

for C. inconspicua (weight of about $449 \mathrm{bp}$ ). Under the same conditions, in case of $K$. unispora, Santiago-Urbina et al. [47] obtained amplification product with a molecular weight of $790 \mathrm{bp}$, whereas, in this study, the same strain showed a molecular weight of $690 \mathrm{bp}$. We observed that, after electrophoretic separation of the PCR products as a result of a determined length of amplicons and the use of restriction enzyme HaeIII, the molecular weights of the PCR products for all strains of $D$. hansenii yeast were similar to those presented by Esteve-Zarzoso et al. [48]. The authors using the same primers for $D$. hansenii 10386 strain obtained PCR products with the molecular weights of 420, 150, and $90 \mathrm{bp}$. According to the data presented by Esteve-Zarzoso et al. [48], as a result of DNA cleavage with HaeIII enzyme, the yeast of $K$. marxianus species demonstrated the presence of two bands with their molecular weights similar to those obtained in this study.

The wrong identification of D. hansenii (C. famata teleomorph) as $P$. guilliermondii (C. guilliermondii teleomorph) was pointed by Nishikawa et al., who also emphasized that these strains are extremely difficult to differentiate phenotypically $[49,50]$. In [51], Desnos-Ollivier et al. analyzed the dozens of isolates of different origin with above synonyms and their aim was to assess, using nucleotide sequences, whether phenotypic identification was correct. They concluded, like others [52], that sequencing of ITS (or D1/D2 region) is a good tool for differentiating the species more frequently confused with $D$. hansenii.

Most of the identified strains in studies discussed herein were previously isolated from kefir or kefir grains by other authors (Table 6). The studies confirming the occurrence of $Z$. florentina yeast in kefir samples have not been published so far. But in 2003, Fröhlich-Wyder isolated Zygosaccharomyces florentinus strain from kefir [19]. It is noteworthy that Kurtzman [53] got a proposal of the new genera Zygotorulaspora from the perspective of the multigene sequence analysis. Until now, two species are accepted: Zygotorulaspora florentinus (Basionym: Zygosaccharomyces florentinus) and Zygotorulaspora mrakii (Basionym: Zygosaccharomyces mrakii).

All examined yeast strains were able to assimilate glucose, glycerol, and lactose. According to the CBS-KNAW Collections data, the $C$. inconspicua yeast does not have the ability to assimilate lactose. However, a study has demonstrated its ability to assimilate and ferment whey containing 5\% lactose [54] along with a $1.9 \% \mathrm{v} / \mathrm{v}$ production of alcohol. The isolate of C. inconspicua IG 11 used in this study fermented glucose with a good yield and demonstrated a high resistance to ethanol (18\%) [55]; however, it did not ferment lactose. Leite et al. [32] listed Kazachstania unispora as the nonlactose fermenting yeast. Our earlier analysis confirmed the lack of ability of this isolate to ferment lactose [55].

The study on wastewater composition confirmed that it can be a valuable source of nitrogen, potassium, phosphorus, and other elements in yeast cultures. High percentage of potassium especially in the wastewater results from the characteristics of the raw material-potatoes, which are a rich source of this element. However, it should be taken into account that the chemical composition of this waste depends on many factors, which include, inter alia, potato variety, type of soil and fertilization, and the technology and the efficiency of obtaining starch and deproteinization. Compared to the waste originating from a different region, the wastewater used in this study was characterized by threefold lower share of calcium and lower concentration of protein compounds [13]. Similarly, wastewater obtained in the laboratory deproteinized with sulfuric acid was characterized by a higher share of nitrogen [16]. 
TABLE 6: Yeast strains isolated from kefir and kefir grains: a literature review.

\begin{tabular}{lc}
\hline Strain & References \\
\hline Brettanomyces anomalus & {$[19-21]$} \\
\hline Candida famata & {$[21]$} \\
Candida firmetaria & {$[20,21]$} \\
\hline Candida friedrichii & {$[19,20,22]$} \\
\hline Candida holmii & {$[21]$} \\
\hline Candida humilis & {$[20,21,23]$} \\
\hline Candida inconspicua & {$[19-24]$} \\
\hline Candida kefyr & {$[21,25,26]$} \\
\hline Candida krusei & {$[19,20,25]$} \\
\hline Candida lambica & {$[19,21]$} \\
\hline Candida lipolytica & {$[20,21,23]$} \\
\hline Candida maris & {$[20]$} \\
\hline Candida tannotelerans & {$[19,20]$} \\
\hline Candida tenuis & {$[21,25]$} \\
Candida valida & {$[21]$} \\
\hline Cryptococcus humicolus & {$[19,20]$} \\
\hline Debaryomyces hansenii & {$[19]$} \\
Dekkera anomala & \\
Galactomyces geotrichum & {$[19,21,25]$} \\
\hline Geotrichum candidum & \\
\hline Issatchenkia occidentalis & \\
\hline Issatchenkia orientalis & \\
\hline Kazachstania aerobia & \\
Kazachstania salicola & \\
Kazachstania serovazzii & \\
Kazachstania unispora & {$[21]$} \\
\hline Kluyveromyces bulgaricus & \\
\hline Kluyveromyces fragilis & \\
\hline Cluyromces & \\
\hline
\end{tabular}

Kluyveromyces fragilis

Kluyveromyces lactis var.

lactis

$[19,21,23,26]$

Kluyveromyces lodderae

[21]

Kluyveromyces marxianus

Kluyveromyces marxianus var.

lactis

$[19-22]$

Pichia fermentans

\begin{tabular}{lc}
\hline Pichia fermentans & {$[19-21,23]$} \\
\hline Saccharomyces cerevisiae & {$[19-24]$} \\
\hline Saccharomyces dairensis & {$[20]$} \\
\hline Saccharomyces delbrueckii & {$[19,20]$} \\
\hline Saccharomyces exiguous & {$[19-22,26]$} \\
\hline Saccharomyces fragilis & {$[24]$} \\
\hline Saccharomyces humaticus & {$[26]$} \\
\hline Saccharomyces lactis & {$[24]$} \\
\hline Saccharomyces pastorianus & {$[21]$} \\
\hline Saccharomyces turicensis & {$[20,21]$} \\
\hline Saccharomyces unisporus & {$[19-21,23,26]$} \\
\hline $\begin{array}{l}\text { Schwanniomyces } \\
\text { occidentalis }\end{array}$ & {$[21]$} \\
\hline $\begin{array}{l}\text { Torulaspora } \\
\text { delbrueckii }\end{array}$ & {$[19-21,23]$} \\
\hline
\end{tabular}

TABLE 6: Continued.

\begin{tabular}{lc}
\hline Strain & References \\
\hline Yarrowia lipolytica & {$[19,21,23]$} \\
\hline $\begin{array}{l}\text { Zygosaccharomyces } \\
\text { florentinus }\end{array}$ & {$[19]$} \\
\hline Zygosaccharomyces rouxii & {$[21]$} \\
\hline Zygosaccharomyces sp. & {$[25]$} \\
\hline
\end{tabular}

The available nitrogen forms in wastewater are proteins, amino acids, purines, and pyrimidines. The easy soluble protein fractions get into a potato wastewater containing $2-5 \%$ of solids, of which crude protein represents about $35 \%$ $[56,57]$. Potato proteins have been classified by Pots et al. [58] into three groups: patatin $(43 \mathrm{kDa})$ comprises $38 \%$, protease inhibitors $(4.3-25.0 \mathrm{kDa}) 50 \%$, and other proteins up to $12 \%$ in potato wastewater. Potato carboxypeptidase inhibitor with a molecular weight of $4.3 \mathrm{kDa}$ is extremely thermostable as though it remained soluble even when the high temperatures had been used [59]. There is a probability of the presence of thermostable protein fractions in wastewater after the separation of potato proteins intended for animal feed. However, the electrophoretic analysis of wastewater which we used did not confirm the presence of proteins of potato carboxypeptidase inhibitor fraction or any protein of a weight lower than $250 \mathrm{kDa}$ (Figure S2). Our studies have confirmed the high effectiveness of the deproteinization process in the starch-producing company.

Intracellular lipid content was dependent on the strain and the applied medium. It is assumed that the process of fat accumulation is induced by a $\mathrm{C}: \mathrm{N}$ ratio of greater than 20 , and in the case of some microorganisms it may be higher than 70 [9]. For oleaginous Lipomyces starkeyi yeast, cultured in a synthetic medium containing glucose as the carbon source and ammonium sulfate as the nitrogen source, the highest lipid content in the biomass amounting to $68 \% \mathrm{CDW}$ was obtained when the initial $\mathrm{C}: \mathrm{N}$ ratio was 150 [60]. The effect of the $\mathrm{C}: \mathrm{N}$ ratio on lipid metabolism has been investigated for a number of oleaginous yeasts and molds [8, 61-65]. The $\mathrm{C}: \mathrm{N}: \mathrm{P}$ ratio in the applied control media (YP) with glucose was $6.45: 1: 0.93$, in media with lactose it was $6.78: 1: 0.93$, and with glycerol it was $6.29: 1: 0.93$. Compared to them, the media prepared based on wastewater were characterized by twofold higher $\mathrm{C}: \mathrm{N}$ ratio. In the media with glucose $\mathrm{C}: \mathrm{N}: \mathrm{P}$ ratio was $12.3: 1: 0.204$, with lactose it was $12.93: 1: 0.204$, and for the media with glycerol it was $12.06: 1: 0.204$. It should be noted that the examined media were not characterized by the recommended excess of carbon with respect to nitrogen, and despite this fact the share of lipids in dry weight of the selected strains was significant. Phosphorus is an element essential for the proper growth of the yeast, but its concentration does not affect in any significant manner the intracellular lipid biosynthesis by these microorganisms. It may, however, affect the fatty acid profile. For example, lipids extracted from $C$. utilis yeast biomass obtained from the medium with low phosphate content were characterized by a modified composition [66]. The process of synthesis and accumulation of intracellular lipid is also influenced by the presence of 
cations necessary for the proper activity of ATP-citrate lyase, a key enzyme of fatty acid synthesis de novo [67]. The activity of the enzyme is absolutely dependent on the presence of $\mathrm{Mg}^{2+}$. The magnesium ion content in potato wastewater

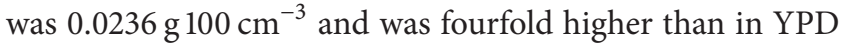
medium [16]. Higher supply of magnesium can be critical to the system. Moreover, $\mathrm{Mn}^{2+}$ and $\mathrm{Co}^{2+}$ could partially substitute $\mathrm{Mg}^{2+}$ deficiency. In this study, $\mathrm{Co}^{2+}$ content was not determined, but high concentration of $\mathrm{Mn}^{2+}$, that is, $0.181 \mathrm{mg} 100 \mathrm{~cm}^{-3}$, was found in the wastewater.

Until now, pure glycerol being used as sole carbon source supported the growth and lipid accumulation of Candida freyschussii and many carotene-producing strains, for example, Rhodotorula glutinis, R. glutinis var. rubescens, and $R$. mucilaginosa $[34,68,69]$. Using a pure form of glycerol as a feedstock for SCO production would be cost-prohibitive for larger-scale production. The composition of the waste glycerol depends on many factors and contains methanol, mono- and diglyceride, free fatty acids, and soap [70]. These substrates may affect the growth and lipid biosynthesis by the yeast. However, no negative effect on growth was observed for Rhodotorula strain when metabolizing biodiesel-derived glycerol, even when using a higher concentration of waste glycerol [71]. During incubation with glycerol and deproteinated potato wastewater yeast isolates showed worse ability to biosynthesis lipids than other strains in media containing glycerol. For example, strain $R$. glutinis var. rubescens produced $4.73 \mathrm{~g}_{\text {lipids } \mathrm{L}^{-1}}$ [34] and Yarrowia lipolytica over $6 \mathrm{~g} \mathrm{~L}^{-1}$, and Candida pulcherrima $7,3 \mathrm{~g} \mathrm{~L}^{-1}$, and Zygosaccharomyces rouxii over $5 \mathrm{gL}^{-1}$ [72]. On the other hand kefir isolates showed a better ability to synthesize lipids compared to, for example, Candida guilliermondii NRRL Y-2075 and several other species (less than $1 \mathrm{~g} \mathrm{~L}^{-1}$ when grown in the defined medium with biodiesel-derived glycerol) analyzed by Papanikolaou et al. [73].

Studies regarding the use of lactose as carbon source during the culture of oleaginous microorganisms are very scarce. To date, only one study related to the effect of lactose on the growth and accumulation of fats by fungi of Trichosporon genus has been conducted [74]. In addition, a study on use of whey for the synthesis SCO involving Saprolegnia diclina fungi that accumulated the lipids at the

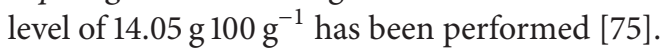

Our results confirm the well-known theory of efficient lipid synthesis in the late stationary phase and at the same time suggest the need to optimize the culture time. We found a large increase in biomass yield and fat content between third and fourth day in the media with lactose, which suggests that lactose is assimilated in a slow manner compared to other carbon sources, which resulted in the biosynthesis of fats observed on fourth day.

The optimal $\mathrm{pH}$ value of the culture medium with respect to promoting lipid biosynthesis by the yeast is in the range of 4-8, depending on the type of microorganism and the used carbon source [76]. An increase in $\mathrm{pH}$ of DPW media, regardless to the strain, was observed during the cultures. The phenomenon of strong alkalization of the media prepared based on DPW was also observed by Nowak et al. during the culture of filamentous fungi [77]. In addition to the available organic nitrogen sources, DPW also contains its unavailable forms in the form of compounds such as amines or imines. Condensation reactions between carbonyl groups contained in the sugars and primary amino groups occur during the preparation of starch and then the separation of potato proteins. The resulting imines (so-called Schiff base) undergo spontaneous rearrangement to the so-called Amadori compounds, which, in turn, polymerize to a brown product, which is poorly characterized so far. Probably, the unavailable organic forms of nitrogen are formed during the culture in the medium and thus may be the reason for alkalization of the medium. However, it should be noted that nitrogen depletion from the medium induces lipids biosynthesis, which causes degradation of cAMP (cyclic adenosine monophosphate) to ammonia and ammonium ion, which may also be the cause of alkalization.

Yeast growth is more effective when the $\mathrm{pH}$ of the medium is slightly acidic, and, therefore, alkalization of the environment may be a stress factor for the cell. A strong alkalization of the environment during yeast culture in DPW disturbs the homeostasis of nutrients and affects an expression of genes of glucose uptake and metabolism. The high $\mathrm{pH}$ causes a temporary drop in the concentration of cAMP and inhibition of protein kinase activator (PKA, protein kinase A). Consequently, the transcription factor $\mathrm{Msn} 2 / 4 \mathrm{p}$ is subject to a rapid activation in the nucleus and activates gene related to stress, related, inter alia, to trehalose synthesis [78]. Perhaps for these reasons, lower content of fat was noted during the culture in DPW medium with glucose compared to other carbon sources. The $\mathrm{pH}$ control in DPW media during the cultures aimed at increasing intracellular biosynthesis of fats appears to be an important issue to be explored. Providing yeast cells with optimum $\mathrm{pH}$ during the culture in media with deproteinized wastewater could result in higher biomass yield and more efficient biosynthesis of fats.

According to the data described in the literature, the temperature of yeast culture aimed at increasing fats biosynthesis should be $25-30^{\circ} \mathrm{C}$. It affects the proliferation rate of the yeast cells and fatty acid composition [5]. Culturing yeast at lower temperatures results in an increased PUFA content. This was proved by Amaretti et al. [65] using Rhodotorula glacialis DBVPG 4785, during which the share of PUFA in biomass, after culturing at a temperature of $0^{\circ} \mathrm{C}$, was the highest and amounted to over $55 \%$.

Fats synthesized by oleaginous yeast primarily contain the following fatty acids: myristic (C14:0), palmitic (C16:0), stearic (C18:0), oleic (C18:1), linoleic (C18:2), and linolenic acid (C18:3) [2]. The primary fatty acid present in the yeast lipids is oleic acid, and it may be even more than $70 \%$ (w/w) (Papanikolaou et al., 2011). The first analysis of the lipids of $D$. hansenii was done by Merdinger and Devine [79]. Our results confirmed fatty acid composition for $D$. hansenii isolates [80]. The fatty acids composition presented remarkable changes as function of incubations time and throughout the life cycle of Debaryomyces. The levels of oleic and palmitoleic acids gradually increased during both the growth phase and the lipid accumulation phase, which coincides with ascosporogenesis, while the concentrations of 
TABLE 7: Biodiesel properties based on the fatty acids composition of the microbial oil producers by kefir yeast strain isolates in different media.

\begin{tabular}{|c|c|c|c|c|c|c|c|c|}
\hline Strain & $\begin{array}{c}\text { Carbon } \\
\text { source }\end{array}$ & $\begin{array}{c}\text { Nitrogen } \\
\text { source }\end{array}$ & UD & $\mathrm{CN}$ & LC & $\begin{array}{c}\mathrm{LCV} \\
\left(\mathrm{kJ} \mathrm{kg}^{-1}\right)\end{array}$ & $\begin{array}{l}\mathrm{FP} \\
\left({ }^{\circ} \mathrm{C}\right) \\
\end{array}$ & $\begin{array}{c}\mu \\
\left(\mathrm{mm}^{2} \mathrm{~s}^{-1}\right)\end{array}$ \\
\hline \multirow{6}{*}{$\begin{array}{l}\text { Candida } \\
\text { inconspicua IG } \\
11\end{array}$} & \multirow{2}{*}{ Glucose } & Peptone & 0,94 & 58 & 17,61 & 35595,71 & 172,41 & 5,32 \\
\hline & & DPW & 1,04 & 53 & 17,65 & 37575,43 & 170,98 & 5,19 \\
\hline & \multirow{2}{*}{ Lactose } & Peptone & 0,77 & 61 & 17,40 & 37560,82 & 170,06 & 5,45 \\
\hline & & DPW & 1,00 & 54 & 17,68 & 37604,87 & 173,07 & 5,27 \\
\hline & \multirow{2}{*}{ Glycerol } & Peptone & 0,84 & 59 & 17,49 & 37573,25 & 170,86 & 5,39 \\
\hline & & DPW & 1,03 & 54 & 17,69 & 37598,66 & 172,62 & 5,24 \\
\hline \multirow{6}{*}{$\begin{array}{l}\text { Debaryomyces } \\
\text { hansenii } 1\end{array}$} & \multirow{2}{*}{ Glucose } & Peptone & 0,88 & 55 & 18,01 & 37813,79 & 189,27 & 5,67 \\
\hline & & DPW & 0,99 & 56 & 17,61 & 37576,05 & 170,99 & 5,25 \\
\hline & \multirow{2}{*}{ Lactose } & Peptone & 0,65 & 65 & 17,45 & 37630,43 & 175,44 & 5,68 \\
\hline & & DPW & 0,70 & 59 & 17,19 & 37474,17 & 164,08 & 5,38 \\
\hline & \multirow{2}{*}{ Glycerol } & Peptone & 0,74 & 58 & 17,44 & 37587,95 & 172,06 & 5,52 \\
\hline & & DPW & 0,91 & 56 & 17,61 & 37559,11 & 169,86 & 5,18 \\
\hline \multirow{6}{*}{$\begin{array}{l}\text { Debaryomyces } \\
\text { hansenii IG II }\end{array}$} & \multirow{2}{*}{ Glucose } & Peptone & 0,75 & 53 & 17,31 & 37522,23 & 167,36 & 5,41 \\
\hline & & DPW & 0,88 & 55 & 17,49 & 37559,45 & 169,84 & 5,33 \\
\hline & \multirow{2}{*}{ Lactose } & Peptone & 0,86 & 51 & 18,21 & 37917,75 & 198,08 & 5,84 \\
\hline & & DPW & 0,92 & 57 & 17,51 & 37553,68 & 169,41 & 5,28 \\
\hline & \multirow{2}{*}{ Glycerol } & Peptone & 0,75 & 57 & 17,24 & 37488,15 & 165,00 & 5,37 \\
\hline & & DPW & 0,92 & 59 & 17,41 & 37504,99 & 166,04 & 5,23 \\
\hline \multirow{6}{*}{$\begin{array}{l}\text { Debaryomyces } \\
\text { hansenii IG } 01\end{array}$} & \multirow{2}{*}{ Glucose } & Peptone & 0,80 & 58 & 17,89 & 37782,18 & 186,87 & 5,72 \\
\hline & & DPW & 0,92 & 58 & 17,58 & 37585,46 & 171,68 & 5,33 \\
\hline & \multirow{2}{*}{ Lactose } & Peptone & 0,86 & 51 & 15,53 & 37585,35 & 171,71 & 5,39 \\
\hline & & DPW & 0,92 & 57 & 17,47 & 37535,54 & 168,15 & 5,26 \\
\hline & \multirow{2}{*}{ Glycerol } & Peptone & 0,75 & 40 & 16,19 & 36976,93 & 135,68 & 4,69 \\
\hline & & DPW & 0,92 & 58 & 17,32 & 37461,17 & 163,09 & 5,16 \\
\hline \multirow{6}{*}{$\begin{array}{l}\text { Kazachstania } \\
\text { unispora IG16 }\end{array}$} & \multirow{2}{*}{ Glucose } & Peptone & 0,70 & 41 & 17,85 & 37804,41 & 188,96 & 5,86 \\
\hline & & DPW & 0,85 & 57 & 16,55 & 37118,81 & 142,77 & 4,79 \\
\hline & \multirow{2}{*}{ Lactose } & Peptone & 0,77 & 59 & 17,34 & 37531,19 & 167,96 & 5,41 \\
\hline & & DPW & 1,05 & 52 & 17,00 & 37256,05 & 150,61 & 4,79 \\
\hline & \multirow{2}{*}{ Glycerol } & Peptone & 0,90 & 56 & 17,02 & 37323,10 & 154,32 & 5,00 \\
\hline & & DPW & 1,06 & 51 & 16,99 & 37100,16 & 142,32 & 4,59 \\
\hline \multirow{6}{*}{$\begin{array}{l}\text { Kluyveromyces } \\
\text { marxianus IG } 1\end{array}$} & \multirow{2}{*}{ Glucose } & Peptone & 0,75 & 45 & 18,19 & 37951,52 & 201,39 & 6,02 \\
\hline & & DPW & 0,89 & 56 & 17,35 & 37488,00 & 164,89 & 5,23 \\
\hline & \multirow{2}{*}{ Lactose } & Peptone & 0,76 & 46 & 18,11 & 37907,84 & 197,52 & 5,94 \\
\hline & & DPW & 0,85 & 59 & 17,25 & 37453,83 & 162,61 & 5,23 \\
\hline & Glycerol & Peptone & 0,85 & 59 & 17,43 & 37542,21 & 168,65 & 5,34 \\
\hline & & DPW & 0,91 & 57 & 17,51 & 37557,56 & 169,69 & 5,30 \\
\hline & Glucose & Peptone & 0,82 & 54 & 17,85 & 37754,23 & 184,57 & 5,66 \\
\hline & Glucose & DPW & 0,85 & 59 & 17,45 & 37554,12 & 169,49 & 5,36 \\
\hline Zygotorulaspora & & Peptone & 0,67 & 55 & 16,12 & 36979,07 & 135,56 & 4,76 \\
\hline florentina IG 12 & Lactose & DPW & 0,81 & 61 & 17,38 & 37535,33 & 168,20 & 5,37 \\
\hline & Glycerol & Peptone & 0,86 & 58 & 17,50 & 37570,52 & 170,64 & 5,36 \\
\hline & Glycerol & DPW & 0,91 & 64 & 17,55 & 37577,03 & 171,08 & 5,33 \\
\hline
\end{tabular}

Unsaturation degree (UN), cetane number (CN), length of chain (LC), low caloric value (LCV), flash point (FP), and viscosity $(\mu)$. 
linoleic, stearic, and palmitic acids decreased towards the start of ascospore formation by $D$. etchellsii [81]. Compared to D. etchellsii, kefir's isolates of Debaryomyces are characterized by significantly higher stearic acid contribution and lower palmitoleic and linoleic acids (in the same growth phase). Fatty acid composition of Kluyveromyces marxianus isolated strain is very similar to Kluyveromyces fragilis CBS 398 [82]. However, isolated strain is distinguished by a significantly lower proportion of linoleic acid. Kazachstania unispora was able to accumulate the high amount of palmitoleic acid. Palmitoleic acid-rich diets have also been reported to improve circulating lipid profile, resulting in reduced total and LDL cholesterol [83]. Palmitoleic acid has been shown to prevent $\beta$-cell apoptosis [84] and inhibit the growth of Grampositive bacteria [85]. Two limited availability sources having high concentrations of palmitoleic acid are sea buckthorn and macadamia nut oil [86]. Regardless of the carbon source, the use of deproteinated potato wastewater promoted palmitoleic acid biosynthesis. The maximum contribution (60\%) of this fatty acid in Kazachstania unispora fat was detected after incubation in DPWGlc medium. The suitability of a microbial strain for producing palmitoleic acid or another fatty acid is dictated by several factors, namely, a combination of a high yield of biomass, proportion of the fatty acid in total FA, and a high percent lipid content under the chosen culture conditions.

The possibility of using fat as a raw material in the production of biodiesel depends on the different physicochemical characteristics of the fuel. The transesterification of microbial oils with a methanol yields to the corresponding monoalkyl esters so the chemical structure of the fatty acids methyl esters influences fuel properties. The successful commercialization of vegetable oils as biodiesel sources has been accompanied by the development of international standards. Some biodiesel standards are European standard EN 14124 and American Society for Testing and Materials ASTM D6751. In our study biodiesel properties were determined using mathematical equations based on the fatty acids compositions. An industrially used biodiesel is primarily composed of palmitic, stearic, oleic, linoleic, and linolenic acids. Biofuels used in Europe are characterized by certain specification, according to which the content of linolenic ester acid should not exceed $12 \%$ and the methyl esters of polyunsaturated fatty acids (containing, inter alia, four double bonds) $-1 \%$ [87]. In addition, a study has demonstrated that the fatty acid exhibiting the best properties affecting improved quality of biodiesel is oleic acid [88]. The presence of unsaturated bonds in the molecule is the primary cause of autoxidation of fats; thus the presence of excess of PUFA esters in the biodiesel considerably reduces its oxidative stability. Culturing yeast at lower temperatures results in an increased PUFA content what is one of the cold-adaptation strategy and unsaturated index for oils is higher. For example, UN for K. marxianus fat received in $4^{\circ} \mathrm{C}$ incubation was 1,06 and only 0,75 in $30^{\circ} \mathrm{C}$ [3]. In addition, the longer the carbon chain of the fatty acid, the higher the fuel viscosity, which unprofitably affects the structural components of cars [89].

The fatty acid composition characteristic for the examined kefir yeast isolates is therefore appropriate in relation to the European Union (EU) requirements for biofuels, and, therefore, they can be a source of SCO. They contain C16:0, C18:0, and C18:2 acids, in particular C18:1. Fats from all strains contained no more than $2.6 \%$ of linolenic acid (C18:3 n-3). The suitable selection of carbon source during culture can reduce the amount of PUFA with more than four double bonds. Biodiesel properties based on the fatty acids composition of the microbial oil producers by kefir yeast strain isolates in different media are shown in Table 7. Cetane number is a primary indicator of fuel quality which is related to the ignition delay time. Cetane (hexadecane, $\left.\mathrm{C}_{16} \mathrm{H}_{34}\right)$ is the high quality standard on the cetane scale with an assigned $\mathrm{CN}$ of 100 . For diesel fuel higher CNs have been correlated with reduction nitrogen oxides $\left(\mathrm{NO}_{x}\right)$ exhaust emission [88]. Unsaturated molecules have higher flame temperatures; thus they increase the formation of $\mathrm{NO}_{x}$ during combustion. According to EN 14214 and ASTM D6751 cetane number of biodiesel should have minimum value of 54 and 47, respectively. The cetane number of kefir yeast oil was high in almost all cases (Table 7). Also flash points are more than $122^{\circ} \mathrm{C}$ (according to EN 14214) making the kefir yeast oils safe to store. Low FP may indicate the presence of methanol in biodiesel [39]. The high kinematic viscosity could affect the atomization of fuel on injection and has impact on injection and combustion. The predicted viscosity of yeast oil produced by the isolates was in all cases high and it means that it would not meet European standards, only ASTM D6751. Factors such a double bond configuration influence viscosity while double bond position affects viscosity less [88]. Another important parameter of a fuel is the low calorific value, which represents the amount of heat transferred to the chamber during combustion and indicates the available energy in a fuel [90]. The average low calorific value of biodiesel all kefir yeast $\left(37,5 \mathrm{MJ} \mathrm{kg}^{-1}\right)$ is lower than petrol $\left(46 \mathrm{MJ} \mathrm{kg}^{-1}\right)$ and diesel fuel $\left(43 \mathrm{MJ} \mathrm{kg}^{-1}\right)$, but higher than coal (32-37 $\left.\mathrm{MJ} \mathrm{kg}^{-1}\right)$ [91].

In conclusion, the isolated kefir yeast strains have demonstrated their ability to biosynthesize intracellular lipids with a concurrent utilization of deproteinated wastewater in this study. Regardless of the carbon source, the use of deproteinated potato wastewater promoted palmitoleic acid biosynthesis by Kazachstania unispora.

\section{Disclosure}

This article does not contain any studies with human participants or animals performed by any of the authors.

\section{Conflicts of Interest}

The authors declare that they have no conflicts of interest.

\section{Acknowledgments}

The authors would like to acknowledge Maria Stańkowska at PEPEES S.A. in Łomża (Poland, Mazovia Voivode) for deproteinated water juice. 


\section{References}

[1] A. Beopoulos and J.-M. Nicaud, "Yeast: A new oil producer?" OCL-Oleagineux Corps Gras Lipides, vol. 19, no. 1, pp. 22-28, 2012.

[2] Q. Li, W. Du, and D. Liu, "Perspectives of microbial oils for biodiesel production," Applied Microbiology and Biotechnology, vol. 80, no. 5, pp. 749-756, 2008.

[3] M. Rossi, P. Buzzini, L. Cordisco et al., "Growth, lipid accumulation, and fatty acid composition in obligate psychrophilic, facultative psychrophilic, and mesophilic yeasts," FEMS Microbiology Ecology, vol. 69, no. 3, pp. 363-372, 2009.

[4] L. Y. Zhu, M. H. Zong, and H. Wu, "Efficient lipid production with Trichosporon fermentans and its use for biodiesel preparation," Bioresource Technology, vol. 99, no. 16, pp. 7881-7885, 2008.

[5] J. M. Ageitos, J. A. Vallejo, P. Veiga-Crespo, and T. G. Villa, "Oily yeasts as oleaginous cell factories," Applied Microbiology and Biotechnology, vol. 90, no. 4, pp. 1219-1227, 2011.

[6] J. Zhang, X. Fang, X.-L. Zhu et al., "Microbial lipid production by the oleaginous yeast Cryptococcus curvatus $\mathrm{O} 3$ grown in fedbatch culture," Biomass and Bioenergy, vol. 35, no. 5, pp. 19061911, 2011.

[7] Y. Li, Z. Zhao, and F. Bai, "High-density cultivation of oleaginous yeast Rhodosporidium toruloides Y4 in fed-batch culture," Enzyme and Microbial Technology, vol. 41, no. 3, pp. 312-317, 2007.

[8] S. Papanikolaou, L. Muniglia, I. Chevalot, G. Aggelis, and I. Marc, "Accumulation of a cocoa-butter-like lipid by Yarrowia lipolytica cultivated on agro-industrial residues," Current Microbiology, vol. 46, no. 2, pp. 124-130, 2003.

[9] S. Papanikolaou and G. Aggelis, "Lipids of oleaginous yeasts. Part II: technology and potential applications," European Journal of Lipid Science and Technology, vol. 113, no. 8, pp. 1052-1073, 2011.

[10] A. A. Koutinas, A. Chatzifragkou, N. Kopsahelis, S. Papanikolaou, and I. K. Kookos, "Design and techno-economic evaluation of microbial oil production as a renewable resource for biodiesel and oleochemical production," Fuel, vol. 116, pp. 566$577,2014$.

[11] I. R. Sitepu, M. Jin, J. E. Fernandez, L. Da Costa Sousa, V. Balan, and K. L. Boundy-Mills, "Identification of oleaginous yeast strains able to accumulate high intracellular lipids when cultivated in alkaline pretreated corn stover," Applied Microbiology and Biotechnology, vol. 98, no. 17, pp. 7645-7657, 2014.

[12] M. Markiewicz, A. Przewodowska, W. Przewodowski, and W. Stochła, "Wykorzystanie chromatografii membranowej do odzyskiwania białek aktywnych biologicznie z odpadów przemysłu skrobiowego," Annual Set The Environment Protection Rocznik Ochrona Środowiska, vol. 17, pp. 1699-1714, 2015.

[13] Z. Lubiewski, H. Smigielska, G. Lewandowicz, and W. Balcerek, "Charakterystyka odcieku po koagulacji białka pozyskiwanego w toku kampanii krochmalniczej," Zeszyty Problemowe Postepów Nauk Rolniczych, vol. 511, pp. 617-626, 2006.

[14] A. M. Kot, S. Błażejak, A. Kurcz, and I. Gientka, "Biodegradation of deproteinized potato wastewater and glycerol during cultivation of Rhodotorula glutinis yeast," Electronic Journal of Biotechnology, vol. 18, no. 6, pp. 428-432, 2015.

[15] S. Łabendziński, "Surowce niekonwencjonalne dla przemysłowej biosyntezy białka. II. Odpady przemysłu krochmalniczego," Przem Ferm Rol, vol. 20, pp. 1-3, 1976.
[16] A. Bzducha-Wróbel, S. Błażejak, M. Molenda, and L. Reczek, "Biosynthesis of $\beta(1,3) /(1,6)$-glucans of cell wall of the yeast Candida utilis ATCC 9950 strains in the culture media supplemented with deproteinated potaoe juice water and glycerol," European Food Research and Technology, vol. 240, no. 5, pp. 1023-1034, 2015.

[17] S. Papanikolaou and G. Aggelis, "Lipid production by Yarrowia lipolytica growing on industrial glycerol in a single-stage continuous culture," Bioresource Technology, vol. 82, no. 1, pp. 43-49, 2002.

[18] J. R. M. Almeida, L. C. L. Fávaro, and B. F. Quirino, "Biodiesel biorefinery: Opportunities and challenges for microbial production of fuels and chemicals from glycerol waste," Biotechnology for Biofuels, vol. 5, article 48, 2012.

[19] M. T. Fröhlich-Wyder, "Yeasts in dairy products," in Yeasts in food. Beneficial and Detrimental Aspects, T. Boekhout and V. Robert, Eds., pp. 209-237, CRC Press, Boca Raton, Fla, USA, 2003.

[20] E. R. Farnworth, "Kefir-a complex probiotic," Food Science Technology Bulletin: Functional Foods, vol. 2, no. 1, pp. 1-17, 2005.

[21] F. Lopitz-Otsoa, A. Rementeria, N. Elguezabal, and J. Garaizar, "Kefir:a symbiotic yeasts-bacteria community with alleged healthy capabilities," Revista Iberoamericana de Micología, vol. 23, no. 2, pp. 67-74, 2006.

[22] G. H. Fleet, "Yeasts in dairy products," Journal of Applied Bacteriology, vol. 68, no. 3, pp. 199-211, 1990.

[23] E. Simova, D. Beshkova, A. Angelov, T. Hristozova, G. Frengova, and Z. Spasov, "Lactic acid bacteria and yeasts in kefir grains and kefir made from them," Journal of Industrial Microbiology and Biotechnology, vol. 28, no. 1, pp. 1-6, 2002.

[24] M. M. Assadi, R. Pourahmad, and N. Moazami, "Use of isolated kefir starter cultures in kefir production," World Journal of Microbiology and Biotechnology, vol. 16, no. 6, Article ID 278340, pp. 541-543, 2000.

[25] R. C. Witthuhn, T. Schoeman, and T. J. Britz, "Characterisation of the microbial population at different stages of Kefir production and Kefir grain mass cultivation," International Dairy Journal, vol. 15, no. 4, pp. 383-389, 2005.

[26] L. Latorre-García, L. Del Castillo-Agudo, and J. Polaina, “Taxonomical classification of yeasts isolated from kefir based on the sequence of their ribosomal RNA genes," World Journal of Microbiology and Biotechnology, vol. 23, no. 6, pp. 785-791, 2007.

[27] C. Garofalo, A. Osimani, V. Milanović et al., "Bacteria and yeast microbiota in milk kefir grains from different Italian regions," Food Microbiology, vol. 49, no. 1, pp. 123-133, 2015.

[28] S. Otes and O. Cagindi, "Kefir: A probiotic dairy-composition, nutritional and aspects," Pakistan Journal of Nutrition, vol. 2, no. 2, pp. 54-59, 2003.

[29] B. Cheirsilp, H. Shimizu, and S. Shioya, "Enhanced kefiran production by mixed culture of Lactobacillus kefiranofaciens and Saccharomyces cerevisiae," Journal of Biotechnology, vol. 100, no. 1, pp. 43-53, 2003.

[30] H. Maeda, X. Zhu, S. Suzuki, K. Suzuki, and S. Kitamura, "Structural characterization and biological activities of an exopolysaccharide kefiran produced by Lactobacillus kefiranofaciens WT$2 \mathrm{~B}^{T}$," Journal of Agricultural and Food Chemistry, vol. 52, no. 17, pp. 5533-5538, 2004.

[31] T. Furuno and M. Nakanishi, "Kefiran suppresses antigeninduced mast cell activation," Biological and Pharmaceutical Bulletin, vol. 35, no. 2, pp. 178-183, 2012. 
[32] A. M. D. O. Leite, M. A. L. Miguel, R. S. Peixoto, A. S. Rosado, J. T. Silva, and V. M. F. Paschoalin, "Microbiological, technological and therapeutic properties of kefir: a natural probiotic beverage," Brazilian Journal of Microbiology, vol. 44, no. 2, pp. 341-349, 2013.

[33] P. Álvarez-Martín, A. B. Flórez, A. Hernández-Barranco, and B. Mayo, "Interaction between dairy yeasts and lactic acid bacteria strains during milk fermentation," Food Control, vol. 19, no. 1, pp. 62-70, 2008.

[34] I. Gientka, M. Gadaszewska, S. Błażejak et al., "Evaluation of lipid biosynthesis ability by Rhodotorula and Sporobolomyces strains in medium with glycerol," European Food Research and Technology, vol. 243, no. 2, pp. 275-286, 2017.

[35] J. L. R. Fietto, R. S. Araújo, F. N. Valadão et al., "Molecular and physiological comparisons between Saccharomyces cerevisiae and Saccharomyces boulardii," Canadian Journal of Microbiology, vol. 50, no. 8, pp. 615-621, 2004.

[36] S. Kumar, G. Stecher, and K. Tamura, "MEGA7: Molecular Evolutionary Genetics Analysis version 7.0 for bigger datasets," Molecular Biology and Evolution, vol. 33, no. 7, pp. 1870-1874, 2016.

[37] G. Zhang, W. T. French, R. Hernandez, E. Alley, and M. Paraschivescu, "Effects of furfural and acetic acid on growth and lipid production from glucose and xylose by Rhodotorula glutinis," Biomass and Bioenergy, vol. 35, no. 1, pp. 734-740, 2011.

[38] M. Kieliszek, S. Błazejak, and A. Bzducha-Wróbel, "Influence of selenium content in the culture medium on protein profile of yeast cells Candida utilisATCC 9950," Oxidative Medicine and Cellular Longevity, vol. 2015, Article ID 659750, 6 pages, 2015.

[39] S. Pinzi, D. Leiva, G. Arzamendi, L. M. Gandia, and M. P. Dorado, "Multiple response optimization of vegetable oils fatty acid composition to improve biodiesel physical properties," Bioresource Technology, vol. 102, no. 15, pp. 7280-7288, 2011.

[40] M. J. Ramos, C. M. Fernández, A. Casas, L. Rodríguez, and Á. Pérez, "Influence of fatty acid composition of raw materials on biodiesel properties," Bioresource Technology, vol. 100, no. 1, pp. 261-268, 2009.

[41] K. Tamura and M. Nei, "Estimation of the number of nucleotide substitutions in the control region of mitochondrial DNA in humans and chimpanzees," Molecular Biology and Evolution, vol. 10, pp. 512-526, 1993.

[42] A. E.-L. Hesham, V. Wambui, H. Ogola J. O., and J. M. Maina, "Phylogenetic analysis of isolated biofuel yeasts based on 5.8SITS rDNA and D1/D2 26S rDNA sequences," Journal of Genetic Engineering and Biotechnology, vol. 12, no. 1, pp. 37-43, 2014.

[43] T. J. White, T. Bruns, S. Lee, and J. Taylor, "Amplification and direct sequencing of fungal ribosomal RNA genes for phylogenetics," in PCR Protocols: A Guide to Methods and Applications, M. A. Innis, D. H. Gefland, J. J. Sninsky, and T. J. White, Eds., pp. 315-322, Academic Press, New York, NY, USA, 1990, https://doi.org/10.1016/b978-0-12-372180-8.50042-1.

[44] Y. C. Chen, J. D. Eisner, M. M. Kattar et al., "Identification of medically important yeasts using PCR-based detection of DNA sequence polymorphisms in the internal transcribed spacer 2 region of the rRNA genes," Journal of Clinical Microbiology, vol. 38, no. 6, pp. 2302-2310, 2000.

[45] S. I. Fujita, Y. Senda, S. Nakaguchi, and T. Hashimoto, "Multiplex PCR using internal transcribed spacer 1 and 2 regions for rapid detection and identification of yeast strains," Journal of Clinical Microbiology, vol. 39, no. 10, pp. 3617-3622, 2001.
[46] X. Połomska, P. Juszczyk, N. Cadež, P. Raspor, M. Robak, and M. Wojtatowicz, "Comparition of physiological and PCRRFLP rDNA identification of yeast species commonly found in cheese," Polish Journal Of Food And Nutrition Sciences, vol. 57, no. 2, pp. 221-226, 2007.

[47] J. A. Santiago-Urbina, J. A. Arias-García, and F. Ruiz-Terán, "Yeast species associated with spontaneous fermentation of taberna, a traditional palm wine from the southeast of Mexico," Annals of Microbiology, vol. 65, no. 1, pp. 287-296, 2015.

[48] B. Esteve-Zarzoso, C. Belloch, F. Uruburu, and A. Querol, "Identification of yeasts by RFLP analysis of the 5.8S rRNA gene and the two ribosomal internal transcribed spacers," International Journal of Systematic Bacteriology, vol. 49, no. 1, pp. 329-337, 1999.

[49] A. Nishikawa, T. Sugita, and T. Shinoda, "Differentiation between Debaryomyces hansenii/Candida famata complex and Candida guilliermondii by polymerase chain reaction," FEMS Immunology and Medical Microbiology, vol. 19, no. 2, pp. 125129, 1997.

[50] A. Nishikawa, H. Tomomatsu, T. Sugita, R. Ikeda, and T. Shinoda, "Taxonomic position of clinical isolates of Candida famata," Medical Mycology, vol. 34, no. 6, pp. 411-419, 1996.

[51] M. Desnos-Ollivier, M. Ragon, V. Robert, D. Raoux, J.-C. Gantier, and F. Dromer, "Debaryomyces hansenii (Candida famata), a rare human fungal pathogen often misidentified as Pichia guilliermondii (Candida guilliermondii)," Journal of Clinical Microbiology, vol. 46, no. 10, pp. 3237-3242, 2008.

[52] A. J. Mota, G. N. Back-Brito, and F. G. Nobrega, "Molecular identification of pichia guilliermondii,debaryomyces hansenii and candida palmioleophila," Genetics and Molecular Biology, vol. 35, no. 1, pp. 122-125, 2012.

[53] C. P. Kurtzman, "Phylogenetic circumscription of Saccharomyces, Kluyveromyces and other members of the Saccharomycetaceae, and the proposal of the new genera Lachancea, Nakaseomyces, Naumovia, Vanderwaltozyma and Zygotorulaspora," FEMS Yeast Research, vol. 4, no. 3, pp. 233-245, 2003.

[54] M. Dahiya and S. Vij, "Comparative analysis of bioethanol production from whey by different strains of immobilized thermotorelant yeast," International Journals of Scientific Research Publications, vol. 2, no. 3, pp. 1-5, 2012.

[55] I. Gientka and E. Klusek, "Kefir jako źródło drożdży tolerujących duże stężenia etanolu," Zeszyty Problemowe Postępów Nauk Rolniczych, vol. 575, pp. 43-51, 2013.

[56] D. Knorr, "Protein quality of the potato and potato protein concentrates," Lebensmittel-Wissenschaft \& Technologie, vol. 11, pp. 109-115, 1978.

[57] G. A. van Koningsveld, H. Gruppen, H. H. J. de Jongh et al., "The solubility of potato proteins from industrial potato fruit juice as influenced by $\mathrm{pH}$ and various additives," Journal of the Science of Food and Agriculture, vol. 82, pp. 134-142, 2001.

[58] A. M. Pots, H. Gruppen, M. Hessing, M. A. J. S. Van Boekel, and A. G. J. Voragen, "Isolation and characterization of patatin isoforms," Journal of Agricultural and Food Chemistry, vol. 47, no. 11, pp. 4587-4592, 1999.

[59] V. Bártová and J. Bárta, "Effect of heat treatment on re-solubility of potato proteins isolated from industrial potato fruit juice," Research in Agricultural Engineering, vol. 54, no. 4, pp. 170-175, 2008.

[60] C. Angerbauer, M. Siebenhofer, M. Mittelbach, and G. M. Guebitz, "Conversion of sewage sludge into lipids by Lipomyces starkeyi for biodiesel production," Bioresource Technology, vol. 99, no. 8, pp. 3051-3056, 2008. 
[61] W.-S. Park, P. A. Murphy, and B. A. Glatz, "Lipid metabolism and cell composition of the oleaginous yeast Apiotrichum curvatum grown at different carbon to nitrogen ratios," Canadian Journal of Microbiology, vol. 36, no. 5, pp. 318-326, 1990.

[62] L.-M. Granger, P. Perlot, G. Goma, and A. Pareilleux, "Kinetics of growth and fatty acid production of Rhodotorula glutinis," Applied Microbiology and Biotechnology, vol. 37, no. 1, pp. 13-17, 1992.

[63] H.-D. Jang, Y.-Y. Lin, and S.-S. Yang, "Effect of culture media and conditions on polyunsaturated fatty acids production by Mortierella alpina," Bioresource Technology, vol. 96, no. 15, pp. 1633-1644, 2005.

[64] S. Wu, C. Hu, G. Jin, X. Zhao, and Z. K. Zhao, "Phosphatelimitation mediated lipid production by Rhodosporidium toruloides," Bioresource Technology, vol. 101, no. 15, pp. 6124-6129, 2010.

[65] A. Amaretti, S. Raimondi, M. Sala et al., "Single cell oils of the cold-adapted oleaginous yeast Rhodotorula glacialis DBVPG 4785," Microbial Cell Factories, vol. 9, article 73, 2010.

[66] J. B. M. Rattray, A. Schibeci, and D. K. Kidby, "Lipids of yeasts," Bacteriological Reviews, vol. 39, no. 3, pp. 197-231, 1975.

[67] C. A. Boulton and C. Ratledge, "Partial purification and some properties of ATP: Citrate lyase from the oleaginous yeast Lipomyces starkeyi," Journal of General Microbiology, vol. 129, pp. 2863-2869, 1983.

[68] E. R. Easterling, W. T. French, R. Hernandez, and M. Licha, "The effect of glycerol as a sole and secondary substrate on the growth and fatty acid composition of Rhodotorula glutinis," Bioresource Technology, vol. 100, no. 1, pp. 356-361, 2009.

[69] A. Amaretti, S. Raimondi, A. Leonardi, and M. Rossi, "Lipid production from glycerol by Candida Freyschuss," in Proceedings of FEMS 2011 14th Congress of European Microbiologists, p. 126, Geneva, Switzerland, 2011.

[70] A. Chatzifragkou and S. Papanikolaou, "Effect of impurities in biodiesel-derived waste glycerol on the performance and feasibility of biotechnological processes," Applied Microbiology and Biotechnology, vol. 95, no. 1, pp. 13-27, 2012.

[71] G. Munch, R. Sestric, R. Sparling, D. B. Levin, and N. Cicek, "Lipid production in the under-characterized oleaginous yeasts, Rhodosporidium babjevae and Rhodosporidium diobovatum, from biodiesel-derived waste glycerol," Bioresource Technology, vol. 185, pp. 49-55, 2015.

[72] A. Chatzifragkou, A. Makri, A. Belka et al., "Biotechnological conversions of biodiesel derived waste glycerol by yeast and fungal species," Energy, vol. 36, no. 2, pp. 1097-1108, 2011.

[73] S. Papanikolaou, M. Rontou, A. Belka et al., "Conversion of biodiesel-derived glycerol into biotechnological products of industrial significance by yeast and fungal strains," Engineering in Life Sciences, vol. 17, no. 3, pp. 262-281, 2017.

[74] M. K. Tahoun, Z. El-Merheb, A. Salam, and A. Youssef, "Biomass and lipids from lactose or whey by Trichosporon beigelii," Biotechnology and Bioengineering, vol. 29, no. 3, pp. 358-360, 1987.

[75] A. Akpinar-Bayizit, T. Ozcan, L. Yilmaz-Ersan, and F. Basoglu, "A Research on whey as a renewable substrate for single cell oil production by Saprolegnia diclina," International Journal of Chemical Engineering and Applications, vol. 7, no. 1, pp. 56-61, 2016.

[76] M. Enshaeieh, A. Abdoli, I. Nahvi, and M. Madani, "Bioconversion of different carbon sources into microbial oil and biodiesel using oleaginous yeasts," Journal of Cell and Molecular Research, vol. 5, no. 1, pp. 17-23, 2013.
[77] J. Nowak, B. Górna, and W. Nowak, "Wykorzystanie grzybów strzępkowych do biodegradacji ścieków z przemysłu ziemniaczanego $\mathrm{z}$ jednoczesną produkcją biomasy pleśniowej na cele paszowe," Żywność. Nauka. Technologia. Jakość/Food.Science .Technology.Quality, vol. 6, no. 91, pp. 191-203, 2013.

[78] C. Casado, A. González, M. Platara, A. Ruiz, and J. Ariño, "The role of the protein kinase A pathway in the response to alkaline pH stress in yeast," Biochemical Journal, vol. 438, no. 3, pp. 523533, 2011.

[79] E. Merdinger and E. M. Devine, "Lipids of Debaryomyces hansenii," Journal of Bacteriology, vol. 89, pp. 1488-1493, 1965.

[80] C. Ratledge and K.-H. Tan, Yeast Biotechnology and Biocatalysis, Marcel Dekker, New York, NY, USA, 1990.

[81] F. Arous, I.-E. Triantaphyllidou, T. Mechichi, S. Azabou, M. Nasri, and G. Aggelis, "Lipid accumulation in the new oleaginous yeast Debaryomyces etchellsii correlates with ascosporogenesis," Biomass and Bioenergy, vol. 80, pp. 307-315, 2015.

[82] J. H. Janssen, N. Burris, A. Woodward, and R. B. Bailey, "Lipid-enhanced ethanol production by Kluyveromyces fragilis," Applied and Environmental Microbiology, vol. 45, no. 20, pp. 598-602, 1983.

[83] A. E. Griel, Y. M. Cao, D. D. Bagshaw, A. M. Cifelli, B. Holub, and etal., "A macadamia nut-rich diet reduces total and LDLcholesterol in mildly hypercholesterolemic men and women," Journal of Nutrition, vol. 138, pp. 761-767, 2008.

[84] N. G. Morgan and S. Dhayal, "Unsaturated fatty acids as cytoprotective agents in the pancreatic B-cell," Prostaglandins Leukotrienes and Essential Fatty Acids, vol. 82, no. 4-6, pp. 231236, 2010.

[85] J. J. Wille and A. Kydonieus, "Palmitoleic acid isomer (C16:1 $\Delta 6)$ in human skin sebum is effective against gram-positive bacteria," Skin Pharmacology and Applied Skin Physiology, vol. 16, no. 3, pp. 176-187, 2003.

[86] I. Kolouchová, K. Sigler, O. Schreiberová, J. Masák, and T. Rezanka, "New yeast-based approaches in production of palmitoleic acid," Bioresource Technology, vol. 192, pp. 726-734, 2015.

[87] B. Sajjadi, A. A. A. Raman, and H. Arandiyan, "A comprehensive review on properties of edible and non-edible vegetable oilbased biodiesel: Composition, specifications and prediction models," Renewable and Sustainable Energy Reviews, vol. 63, pp. 62-92, 2016.

[88] G. Knothe, "Dependence of biodiesel fuel properties on the structure of fatty acid alkyl esters," Fuel Processing Technology, vol. 86, no. 10, pp. 1059-1070, 2005.

[89] R. K. Saluja, V. Kumar, and R. Sham, "Stability of biodiesel-a review," Renewable and Sustainable Energy Reviews, vol. 62, pp. 866-881, 2016.

[90] A. Demirbas, "Comparison of transesterification methods for production of biodiesel from vegetable oils and fats," Energy Conversion and Management, vol. 49, no. 1, pp. 125-130, 2008.

[91] L. E. Oliveira and M. L. C. P. Da Silva, "Comparative study of calorific value of rapeseed, soybean, jatropha curcas and crambe biodiesel," Renewable Energies and Power Quality Journal, vol. 1, no. 11, pp. 679-682, 2013. 

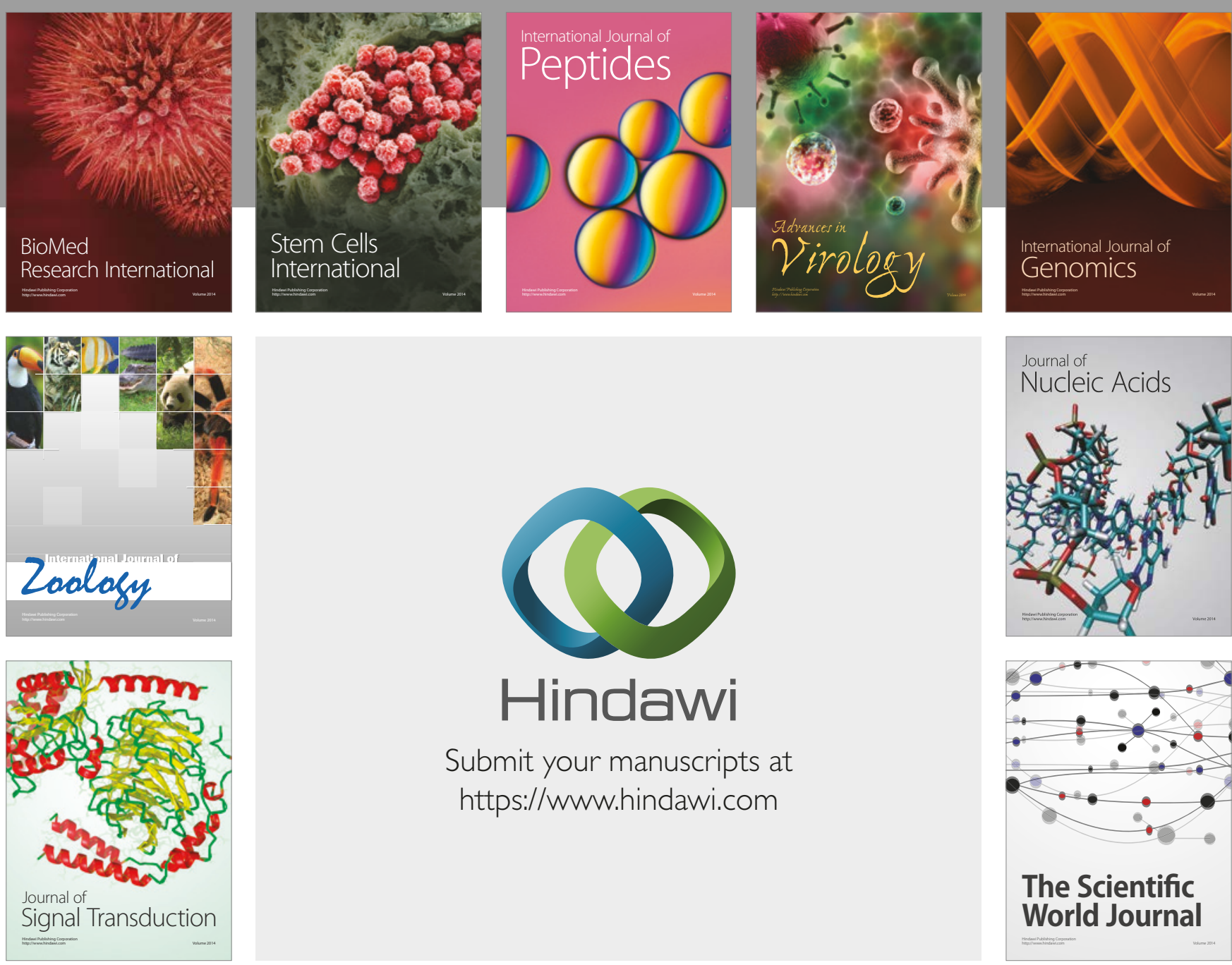

Submit your manuscripts at

https://www.hindawi.com
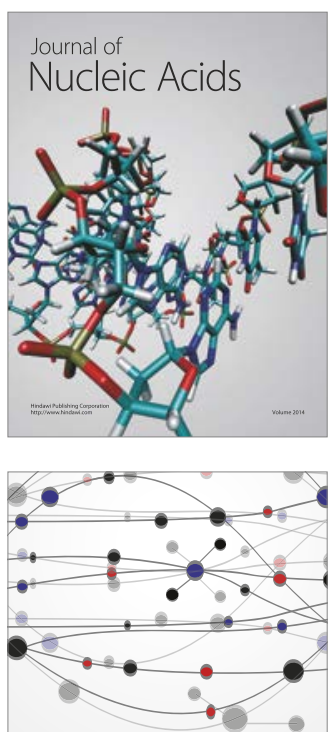

The Scientific World Journal

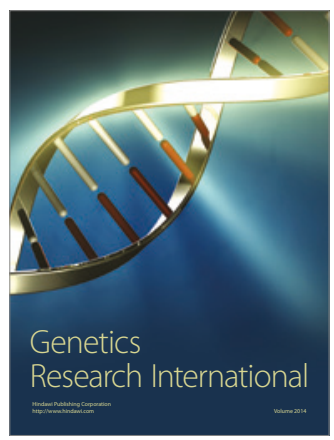

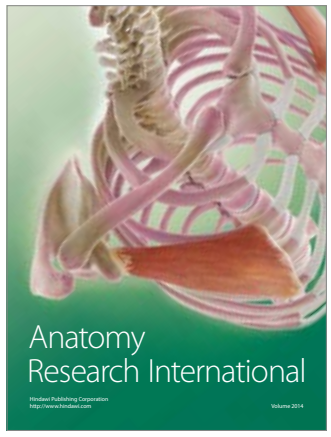

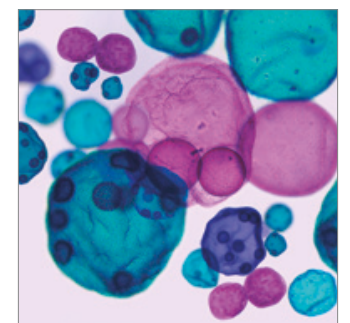

International Journal of Microbiology
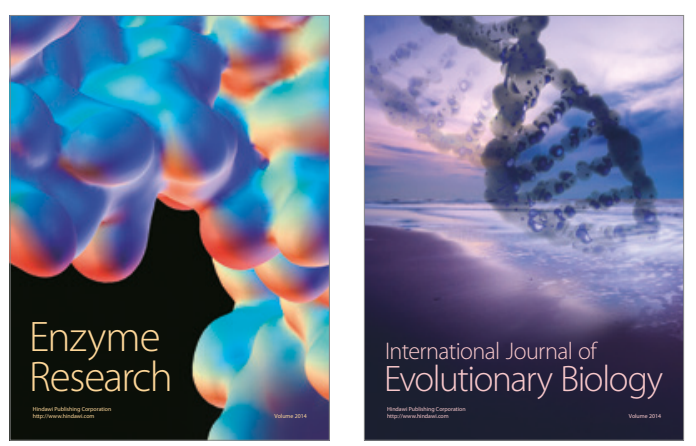
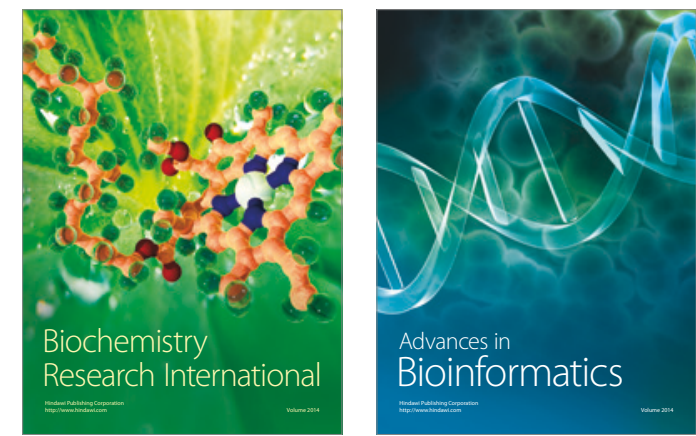

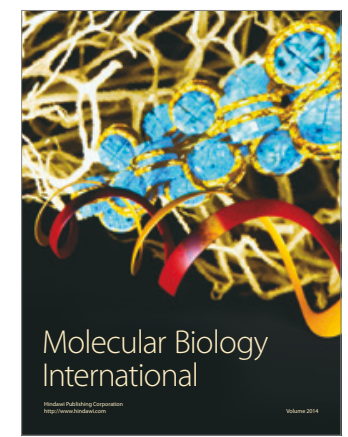

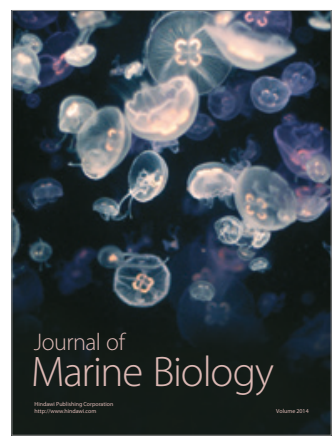

